\title{
The role of internal corporate governance mechanisms on default risk: A systematic review for different institutional settings
}

\author{
Laura Ballester $^{\mathrm{a}, *}$, Ana González-Urteaga ${ }^{\mathrm{b}, \mathrm{c}}$, Beatriz Martínez ${ }^{\mathrm{c}}$ \\ ${ }^{a}$ University of Valencia, Avda. Los Naranjos $s / n, 46022$ Valencia, Spain \\ ${ }^{\mathrm{b}}$ Institute for Advanced Research in Business and Economics (INARBE), 31006, Pamplona, Spain \\ ${ }^{\mathrm{c}}$ Public University of Navarre, Arrosadia Campus, 31006 Pamplona, Spain
}

\section{A R T I C L E I N F O}

\section{Keywords:}

Credit risk

Corporate governance

Institutional setting

JEL classification:

G34

G32

G15

\begin{abstract}
A B S T R A C T
Recent financial downturns, characterized by the significant failures of firms, have revealed the need to control credit risk. Latest literature has shown that weak corporate governance structures are related to high levels of default risk, leading to financial instability. In this context, we aim to summarize the literature that focuses on the role that internal corporate governance plays in the credit risk of firms, specifically considering three corporate governance components: ownership structure, board structure and financial stakeholders' rights and relations. Additionally, we analyse whether the effectiveness of the internal mechanisms depends on particular key factors, especially the institutional setting and the type of mechanisms considered. Finally, new lines of research are identified for future research.
\end{abstract}

\section{Introduction}

Recent financial crises have been characterized by, among other things, credit risk measures reaching unprecedented levels, largescale defaults and banking system bailouts. As a result, attention has focused on the importance of the study of risk management, especially credit risk. In this context, our main purpose is to present the key findings from previous papers on the relationship between internal corporate governance and credit risk, and identify which structures have proved to be effective in reducing the default risk of firms.

Previous research on internal corporate governance has mainly focused on the relationship between alternative mechanisms and firm value. There is an extensive body of literature that has led to the development of systematic reviews on the topic, including John et al. (2016) and Schiehll and Martins (2016). However, firm performance only offers a partial picture of a firm's financial and economic situation, which would be enlarged by considering other factors such as leverage or firm volatility. Our work contributes by considering the conjunction of all these factors that comprise the firm's likelihood to fail, that is, the firm's default risk. With this purpose in mind, it is necessary to identify what the determinants of the probability of default are and to understand how they affect that probability.

In addition to this, we improve on the existing literature by presenting the key differences among institutional settings, which is the main focus of this review, but we also analyse differences based on the type of company and time period. In addition, we highlight the importance of using appropriate credit risk measures and the methodology employed. Additionally, we improve the current literature by identifying some remaining gaps and suggesting directions for future research to be addressed by researchers. An understanding of the corporate governance practices of firms and their implications with respect to default risk for different

\footnotetext{
* Corresponding author.

E-mail address: laura.ballester@uv.es (L. Ballester).
} 
institutional settings is vital for several reasons. First, it is important to know what corporate governance practices taken by firms can lead to business failures, and the mechanisms that can be adopted to prevent them. As Pirson and Turnbull (2015) point out, failures in corporate governance was one of the origins of the 2008 financial crisis, whose impact could have been mitigated much earlier if stronger corporate governance systems had been available. Second, the importance of corporate governance on firm risk has also been considered by the credit rating agencies that incorporate corporate governance mechanisms in their assessments of credit risk (Louizi and Kammoun, 2016). Those mechanisms that reduce the default risk of companies will be considered as good corporate governance actions. Finally, it is necessary to understand if the effect of the different corporate governance mechanisms on credit risk depends on the institutional environment. We argue that conclusions from agency theory regarding good corporate governance practices must be treated with caution, since this theory does not take into account the peculiarities of other institutional settings outside the Anglo-Saxon model.

We observe that although it would be expected that good corporate governance mechanisms reduce firm default risk, previous empirical papers show a lack of consensus on what the best governance structure is to achieve this reduction. In this context, our review would facilitate the discussion of the scope of the different factors and contribute by disentangling which of them plays a leading role when a certain internal mechanism reduces the default risk. In this regard, we analyse three governance components developed by Standard \& Poor's for assessing corporate governance: ownership structure, board structure, and financial stakeholders' rights and relations.

Regarding the ownership structure, which is the most studied mechanism, we find a lack of consensus on the role played by institutional, insider or financial and non-financial ownership. Whether these types of investors increase or reduce credit risk depends on their heterogeneity: long-term versus short-term institutional investors, managerial versus director ownership, or the relationship between financial or non-financial investors and the company. Therefore, these differences should first be analysed before inferring divergencies based on the institutional setting. There are, however, some interesting results based on the countries the companies pertain to. First, the effect of state ownership on credit risk is positive in emerging countries where the interference of the state is high. Second, the decreasing effect of ownership concentration on credit risk is only found in Asian and European countries, which are characterized by a high concentration of ownership. Third, foreign ownership, which has only been analysed in the Asian context, reduces credit risk in China, where foreign ownership is contrasted against state ownership, and increases credit risk in Japan, India or Islamic countries, whose cultural peculiarities may hinder the adaptation of foreign investors. Finally, family ownership reduces credit risk only in European countries, where the use of excess control rights, which are found to increase credit risk, is lower; however, there is no a consensus in the Asian context.

In relation to the board structure, we obtain some conclusive results. Regardless of the institutional setting, there seems to be a consensus on the positive effect of CEO duality on credit risk and the negative effect of female and foreign directors. However, there is not a consensus on the role played by board independence, which is the most studied board characteristic. In the U.S., a quadratic relationship is found between this mechanism and credit risk, which may explain the mixed results. In addition, while board size seems to decrease credit risk in the North American and U.K. contexts, this relationship is not clear for Asia and Europe. On the other hand, there are other characteristics that have only been studied by a small number of papers and, therefore, conclusions cannot be reached. Some of these are: director and CEO networks, political connections, director tenure, managerial ability or CEO power. Finally, with regard to the corporate governance indices, we find a clear bias towards the institutional setting, since most papers analyse U.S. companies, which makes it impossible to draw conclusions based on the institutional setting. In any case, there is also a lack of consensus for the U.S.

In short, it should be noted that we reach a general common outcome for all internal corporate governance mechanisms and their effect on credit risk. More studies are needed to provide robust conclusions and a clear understanding of the differences between countries. There are several mechanisms for which no consensus is reached, for various reasons, such as the limited number of papers or the need to analyse other determinants in their relationship with credit risk. On the other hand, in the cases of those mechanisms in which the existing relationship seems clearer, it is necessary to expand the analysis either to explicitly compare different institutional settings or to consider certain variables that have been decisive in the analyses performed. In particular, although there is a limited set of papers that analyse differences based on firm type (financial versus non-financial firms) and time period (crisis versus noncrisis) for some mechanisms, more studies are needed in this regard.

This paper proceeds as follows. In the next section we present the methodology employed to select the articles and the internal mechanisms included in the review. Sections 3,4 and 5 analyse the existing literature and describe the main findings in relation to the impact that the three components of corporate governance considered (ownership structure, board structure, and financial stakeholders' rights and relations) have on credit risk, with the main focus put on the differences among papers based on the institutional setting. Section 6 shows other factors, such as the type of firm and time period, which may explain the different results. Next, Sections 7 and 8 provide a description of the alternative measures of credit risk used and the methodology employed, respectively. Finally, Section 9 concludes.

\section{Methodology}

The search for relevant papers is carried out in Web of Science (WoS), specifically the main collection of WoS. The keywords searched in all fields (title, abstract and author's keywords) are "corporate governance" AND "institutional" (OR "board" OR "ownership" OR "duality") AND “default risk" (OR "credit risk" OR "credit rating”). If corporate governance belongs to the general topic of the systematic review, with the second filter we plan to capture the two internal corporate governance mechanisms that we want to analyse (ownership structure and board of directors). The third criteria corresponds to the dependent variable that we 
Table 1

Papers classified by publication years. This table shows the number of papers (among the sample of the 68 papers that we summarize in this systematic review) classified by publication years.

\begin{tabular}{lll}
\hline Publication years & Record Count & $\%$ of 68 \\
\hline 2019 & 1 & $1.47 \%$ \\
2018 & 13 & $19.12 \%$ \\
2017 & 11 & $16.18 \%$ \\
2016 & 14 & $20.59 \%$ \\
2015 & 10 & $14.71 \%$ \\
2014 & 2 & $2.94 \%$ \\
2013 & 2 & $2.94 \%$ \\
2012 & 4 & $5.88 \%$ \\
2011 & 2 & $2.94 \%$ \\
2010 & 2 & $2.94 \%$ \\
2009 & 2 & $2.94 \%$ \\
2008 & 1 & $1.47 \%$ \\
2007 & 2 & $2.94 \%$ \\
2006 & 1 & $1.47 \%$ \\
2003 & 1 & $1.47 \%$ \\
\hline
\end{tabular}

Source: Web of Science.

include in the review (credit risk). We look into all the WoS categories and articles, book chapters and review documents (excluding proceedings papers). We consider papers published in the period running from 1990 to 2019; however, the greatest number of studies start in the 2000s. With this selection criterion we detect 492 papers and, after removing the duplicates copies with the different searches, we obtain an initial sample of 196 research papers to be reviewed. In a second phase, we select those papers that specifically fit with the objective of this systematic review, reading the abstract (or the full text if required) of each paper one by one. With this procedure we obtain the final sample of 68 papers that we summarize in this systematic review. In Appendix A, the 68 studies are indicated with their respective codes, from 1 to 68, presented in alphabetical order.

Table 1 shows the number of papers classified by publication years. We observe that the publication of these papers begins in 2003 and that the years having the most publications are between 2015 and 2018, with around $70 \%$ of the papers. This analysis confirms that the literature on this subject is relatively recent. In addition, Table 2 shows the number of papers classified by the published journal, where we observe that the papers included in this systematic review are of recognized prestige and are situated in high positions within their rankings. As can be seen, of the 43 journals listed, 24 are indexed in the JCR index and of these, 10 (6) are in the first (second) quartile of their category. Except for one journal, the rest belongs to the SJC Scimago index. Of the 42 journals indexed in SJR, 23 (10) are in the first (second) quartile.

Fig. 1 summarizes the citation report for the 68 papers at December, 2019. Specifically, this figure shows the total number of times cited (the total number of citations of all items in the results set) per year for all the 68 papers included in the review (blue line), as well as for the 39 papers that belong to the 14 journals with more than one paper (red line). In both cases, an upward trend is observed throughout the publication sample period, with the peak number of citations reached in 2019 . The total number of times cited in the whole period is $1,886(1,018)$, or 1,778 (989) without self-citations. In addition, the $h$-index of this systematic review is 18 (15) and the average number of citations per item is 27.74 (26.1).

We can see in Table 3 the number of papers by country sample. We observe that around $75 \%$ of papers (51/68) analyse one single-country study. Among them, 57 \% (29/51) are from the U.S., followed by China (8\%), Taiwan (6\%), Japan (4\%) and Korea (4\%). There are also papers that analyse Canada, Australia, Italy, UK, India, Indonesia, Philippines, Bangladesh, Malaysia, Tunisia and Egypt. The remaining $25 \%$ (17/68) of papers use a multinational sample that allows comparisons to be made on the effect of corporate governance for different institutional settings. Among the multi-country sample papers, $47 \%$ (8/17) use a sample of companies from several continents, $41 \%$ (7/17) only from Europe and $12 \%$ only from Asia (2/17). However, only 47 \% (8/17) of the multinational studies analyse differences in their findings among countries, although the explanations for the differences are lacking. The remaining multi-country papers, despite having a multinational sample, do not look at differences among settings (Akwaa-Sekyi and Gene, 2017; Andries and Brown, 2017; Auvray and Brossard, 2012; Borisova et al., 2015; Cornett et al., 2010; Froneberg et al., 2016; Iannotta et al., 2013; Mollah and Liljeblom, 2016; Saghi-Zedek, 2016).

In order to check for differences based on the institutional setting, we first analyse whether there is a general pattern in a group of countries with the same result among them, and different results from papers looking at other countries. If that general pattern is not found, we look at the multinational studies and check whether they find differences among countries.

We follow the framework developed by Standard \& Poor's for assessing corporate governance, by analysing three of the governance components they propose: ownership structure and influence, board structure and processes, and financial stakeholders' rights and relations. ${ }^{1}$ The first component is related to the influence that some shareholders exert on management and is studied through the firm's

\footnotetext{
${ }^{1}$ We set aside the fourth component related to the earnings management literature, that of financial transparency and disclosure, which would deserve a separate and deeper analysis.
} 
Table 2

Papers classified by source titles. This table shows the number of papers (from among the sample of 68 papers that we summarize in this systematic review) classified by the published journal. In addition, the JCR-2018 and SJR-2019 impact ratings Q1, Q2, Q3 and Q4 indicate the respective quartiles in which the journal is ranked with respect to the total number of journals belonging to the same category. All journals belong to the category of Business, Finance.

\begin{tabular}{|c|c|c|c|c|c|}
\hline & Source Titles & Record Count & $\%$ of 68 & 2018 JCR Index & 2019 SJR Index \\
\hline 1 & JOURNAL OF BANKING AND FINANCE & 6 & $8.82 \%$ & $2.205(\mathrm{Q} 2)$ & $1.344(\mathrm{Q} 1)$ \\
\hline 2 & RESEARCH IN INTERNATIONAL BUSINESS AND FINANCE & 4 & $5.88 \%$ & $1.467(\mathrm{Q} 3)$ & $0.638(\mathrm{Q} 1)$ \\
\hline 3 & JOURNAL OF FINANCIAL ECONOMICS & 3 & $4.41 \%$ & $4.693(\mathrm{Q} 1)$ & $11.999(\mathrm{Q} 1)$ \\
\hline 4 & JOURNAL OF FINANCIAL SERVICES RESEARCH & 3 & $4.41 \%$ & $1.667(\mathrm{Q} 2)$ & $1.025(\mathrm{Q} 1)$ \\
\hline 5 & MANAGERIAL FINANCE & 3 & $4.41 \%$ & - & $0.248(\mathrm{Q} 3)$ \\
\hline 6 & PACIFIC BASIN FINANCE JOURNAL & 3 & $4.41 \%$ & - & $0.671(\mathrm{Q} 2)$ \\
\hline 7 & REVIEW OF QUANTITATIVE FINANCE AND ACCOUNTING & 3 & $4.41 \%$ & - & $0.669(\mathrm{Q} 1)$ \\
\hline 8 & ACCOUNTING AND FINANCE & 2 & $2.94 \%$ & $1.481(\mathrm{Q} 2)$ & $0.430(\mathrm{Q} 2)$ \\
\hline 9 & ASIA PACIFIC JOURNAL OF ACCOUNTING AND ECONOMICS & 2 & $2.94 \%$ & - & $0.283(\mathrm{Q} 3)$ \\
\hline 10 & JOURNAL OF EMPIRICAL FINANCE & 2 & $2.94 \%$ & $1.244(\mathrm{Q} 3)$ & $1.013(\mathrm{Q} 1)$ \\
\hline 11 & JOURNAL OF FINANCIAL INTERMEDIATION & 2 & $2.94 \%$ & $2.588(\mathrm{Q} 1)$ & $4.747(\mathrm{Q} 1)$ \\
\hline 12 & JOURNAL OF FINANCIAL STABILITY & 2 & $2.94 \%$ & $2.301(\mathrm{Q} 1)$ & $1.627(\mathrm{Q} 1)$ \\
\hline 13 & JOURNAL OF MONEY CREDIT AND BANKING & 2 & $2.94 \%$ & $1.782(\mathrm{Q} 2)$ & $2.403(\mathrm{Q} 1)$ \\
\hline 14 & REVIEW OF FINANCIAL STUDIES & 2 & $2.94 \%$ & $4.975(\mathrm{Q} 1)$ & $12.837(\mathrm{Q} 1)$ \\
\hline 15 & ADVANCES IN ACCOUNTING & 1 & $1.47 \%$ & - & $0.392(\mathrm{Q} 2)$ \\
\hline 16 & ASIA PACIFIC JOURNAL OF FINANCIAL STUDIES & 1 & $1.47 \%$ & - & $0.268(\mathrm{Q} 3)$ \\
\hline 17 & ASIAN JOURNAL OF BUSINESS AND ACCOUNTING & 1 & $1.47 \%$ & - & $0.184(\mathrm{Q} 3)$ \\
\hline 18 & ASIAN REVIEW OF ACCOUNTING & 1 & $1.47 \%$ & - & $0.323(\mathrm{Q} 3)$ \\
\hline 19 & $\begin{array}{l}\text { CANADIAN JOURNAL OF ADMINISTRATIVE SCIENCES REVUE CANADIENNE DES } \\
\text { SCIENCES DE L ADMINISTRATION }\end{array}$ & 1 & $1.47 \%$ & $0.849(\mathrm{Q} 4)$ & 0.324 (Q3) \\
\hline 20 & CHINA JOURNAL OF ACCOUNTING RESEARCH & 1 & $1.47 \%$ & - & $0.520(\mathrm{Q} 2)$ \\
\hline 21 & CONTEMPORARY ACCOUNTING RESEARCH & 1 & $1.47 \%$ & $2.261(\mathrm{Q} 1)$ & $2.207(\mathrm{Q} 1)$ \\
\hline 22 & CORPORATE GOVERNANCE THE INTERNATIONAL JOURNAL OF BUSINESS IN SOCIETY & 1 & $1.47 \%$ & - & - \\
\hline 23 & ECONOMICS OF TRANSITION & 1 & $1.47 \%$ & $0.735(\mathrm{Q} 4)$ & $0.466(\mathrm{Q} 2)$ \\
\hline 24 & EUROPEAN JOURNAL OF FINANCE & 1 & $1.47 \%$ & $1.124(\mathrm{Q} 3)$ & $0.474(\mathrm{Q} 1)$ \\
\hline 25 & FINANCIAL REVIEW & 1 & $1.47 \%$ & - & $0.385(\mathrm{Q} 2)$ \\
\hline 26 & INTANGIBLE CAPITAL & 1 & $1.47 \%$ & - & $0.265(\mathrm{Q} 3)$ \\
\hline 27 & $\begin{array}{l}\text { INTERNATIONAL JOURNAL OF ISLAMIC AND MIDDLE EASTERN FINANCE AND } \\
\text { MANAGEMENT }\end{array}$ & 1 & $1.47 \%$ & $0.750(\mathrm{Q} 4)$ & $0.286(\mathrm{Q} 3)$ \\
\hline 28 & INTERNATIONAL REVIEW OF ECONOMICS AND FINANCE & 1 & $1.47 \%$ & $1.432(\mathrm{Q} 3)$ & $0.813(\mathrm{Q} 1)$ \\
\hline 29 & JOURNAL OF ACCOUNTING AND PUBLIC POLICY & 1 & $1.47 \%$ & $2.269(\mathrm{Q} 1)$ & $1.125(\mathrm{Q} 1)$ \\
\hline 30 & JOURNAL OF ACCOUNTING AND ECONOMICS & 1 & $1.47 \%$ & $3.753(\mathrm{Q} 1)$ & $5.821(\mathrm{Q} 1)$ \\
\hline 31 & JOURNAL OF BUSINESS & 1 & $1.47 \%$ & - & $3.265(\mathrm{Q} 1)$ \\
\hline 32 & JOURNAL OF BUSINESS ETHICS & 1 & $1.47 \%$ & $3.796(Q 1)$ & $1.972(\mathrm{Q} 1)$ \\
\hline 33 & JOURNAL OF CORPORATE FINANCE & 1 & $1.47 \%$ & $2.349(\mathrm{Q} 1)$ & $1.566(\mathrm{Q} 1)$ \\
\hline 34 & JOURNAL OF ECONOMICS AND BUSINESS & 1 & $1.47 \%$ & - & $0.409(\mathrm{Q} 2)$ \\
\hline 35 & JOURNAL OF FINANCIAL ECONOMIC POLICY & 1 & $1.47 \%$ & - & $0.297(\mathrm{Q} 3)$ \\
\hline 36 & JOURNAL OF INTERNATIONAL FINANCIAL MARKETS INSTITUTIONS MONEY & 1 & $1.47 \%$ & $1.836(\mathrm{Q} 2)$ & $1.185(\mathrm{Q} 1)$ \\
\hline 37 & JOURNAL OF LAW ECONOMICS & 1 & $1.47 \%$ & - & $1.575(\mathrm{Q} 1)$ \\
\hline 38 & JOURNAL OF MANAGEMENT AND GOVERNANCE & 1 & $1.47 \%$ & - & $0.555(\mathrm{Q} 2)$ \\
\hline 39 & JOURNAL OF RISK AND INSURANCE & 1 & $1.47 \%$ & $1.795(\mathrm{Q} 2)$ & $1.627(\mathrm{Q} 1)$ \\
\hline 40 & JOURNAL OF RISK FINANCE & 1 & $1.47 \%$ & - & $0.388(\mathrm{Q} 2)$ \\
\hline 41 & MANAGEMENT SCIENCE & 1 & $1.47 \%$ & $4.219(\mathrm{Q} 1)$ & $5.439(\mathrm{Q} 1)$ \\
\hline 42 & MANAGERIAL AUDITING JOURNAL & 1 & $1.47 \%$ & $1.064(\mathrm{Q} 3)$ & $0.468(\mathrm{Q} 1)$ \\
\hline 43 & QUARTERLY JOURNAL OF FINANCE & 1 & $1.47 \%$ & - & $0.709(\mathrm{Q} 2)$ \\
\hline
\end{tabular}

ownership structure. The second component refers to the configuration of the board of directors in term of independence, size, duality, etc., and is studied by looking at the composition of the board. Finally, the third component is related to the balance of power between stakeholders and managers, which is analysed from the different corporate governance indices used in the literature.

In the following sections we analyse the relationship between the three corporate governance components and credit risk. We must highlight that $84 \%(57 / 68)$ of the papers that we analyse consider some type of internal control mechanism as their main determinant of a firm's credit risk, while the remaining $16 \%(11 / 68)$ include them as control variables. In Table 4 we present the number of papers that analyse each internal mechanism, while Table 5 shows their effect on credit risk, where a positive sign indicates an increase in the firm's credit risk, and a negative sign a decrease in its credit risk. ${ }^{2}$ Finally, in Table 6 we present a summary of our main conclusions after analysing the existing literature, in addition to listing future lines of research that have not yet been undertaken. In the three tables the different internal mechanisms are distributed in three panels depending on the corporate governance component to which they belong: Panel A for ownership structure, Panel B for board composition and Panel C for corporate governance indices, which are analysed below in Sections 3,4 and 5, respectively.

\footnotetext{
${ }^{2}$ Additionally, Appendix B combines in a single table the information collected in Tables 3 and 5, with the aim of showing the effect of the institutional environment on the relationship between each internal corporate mechanism and credit risk.
} 


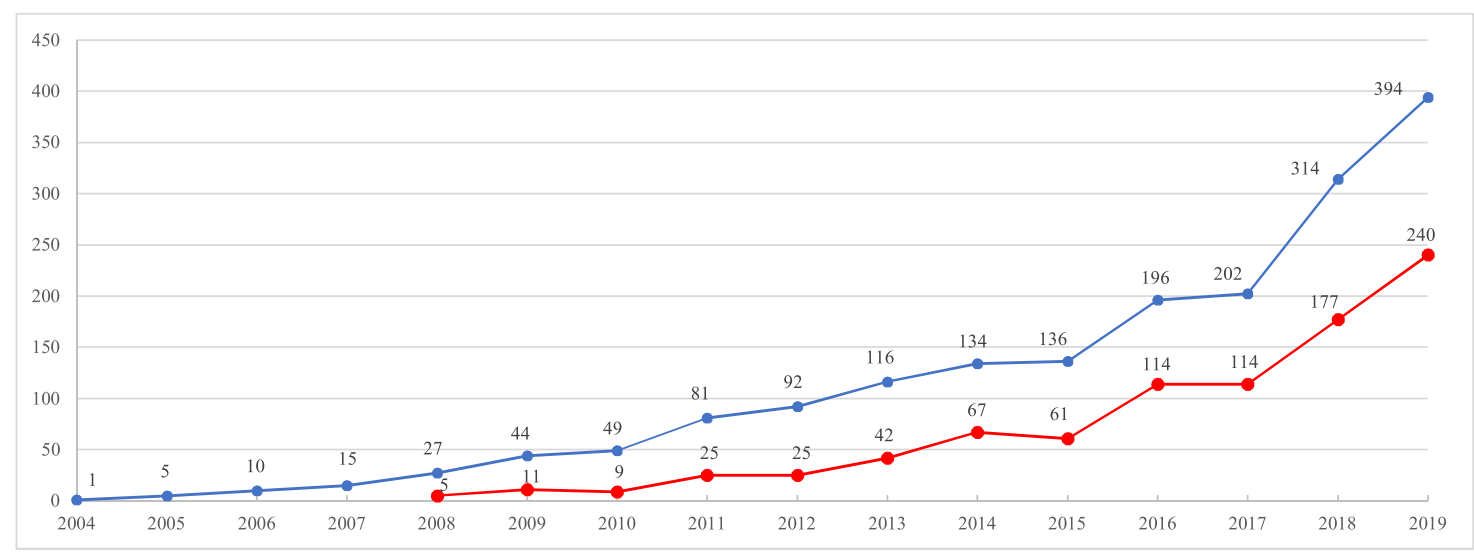

Fig. 1. Number of times cited per year.

This figure shows the time evolution of the total citations per year. The line in blue colour shows the evolution for the sample of the 68 papers that we summarize in this systematic review from 2004 to 2019 . The total number of citations of all items in the results set is 1,886 , or 1,778 without self-citations. In addition, the $h$-index of this systematic review is 18 and the average number of citations per item is 27.74 . The line in red colour shows the time evolution of the total citations per year for the sample of 39 papers (that belongs to the first 14 journals that account for $60 \%$ of the papers that are included in this systematic review) from 2008 to 2019. The total number of times cited is 1,018 , or 989 without self-citations. In addition, the $h$-index of this subsample of papers is 15 and the average number of citations per item is 26.1.

Source: Web of Science.

\section{Table 3}

Empirical papers on the relationship between corporate governance and credit risk by country. This table shows the number of papers (among the sample of the 68 papers that we summarize in this systematic review) by country sample. The papers are identified by numerical codes, from 1 to 68 , following the list indicated in Appendix A.

\begin{tabular}{|c|c|c|}
\hline Country & Papers & No. of papers \\
\hline \multicolumn{2}{|l|}{ Single-country sample } & 51 \\
\hline U.S. & $\begin{array}{l}2,4,6,10,11,12,14,16,18,19,20,22,24,27,31,34,35,40,41,44,47,48 \\
50,54,56,60,61,63,66\end{array}$ & 29 \\
\hline China & $13,23,33,68$ & 4 \\
\hline Taiwan & $25,53,65$ & 3 \\
\hline Japan & 59,64 & 2 \\
\hline Korea & 17,42 & 2 \\
\hline Canada & 57 & 1 \\
\hline Australia & 3 & 1 \\
\hline Italy & 39 & 1 \\
\hline UK & 46 & 1 \\
\hline India & 37 & 1 \\
\hline Indonesia & 62 & 1 \\
\hline Philippines & 58 & 1 \\
\hline Bangladesh & 67 & 1 \\
\hline Malaysia & 29 & 1 \\
\hline Tunisia & 9 & 1 \\
\hline Egypt & 28 & 1 \\
\hline \multicolumn{2}{|l|}{ Multi-country sample } & 17 \\
\hline Europe & $1,5,7,8,38,51,52$ & 7 \\
\hline North America, South America, Europe, Asia, Australia & $15,30,49$ & 3 \\
\hline $\begin{array}{l}\text { North America, South America, Europe, Asia, Australia, } \\
\text { Africa }\end{array}$ & 45 & 1 \\
\hline North America, Europe, Asia, Australia & 32 & 1 \\
\hline South America, Europe, Asia, Australia & 55 & 1 \\
\hline East Asia and Europe & 43 & 1 \\
\hline Gulf Cooperation Council countries and South Asia & 36 & 1 \\
\hline East Asia & 26 & 1 \\
\hline G20 and Taiwan & 21 & 1 \\
\hline
\end{tabular}


Table 4

Empirical papers that consider corporate governance mechanisms as factors of firms' credit risk. This table shows the number of papers (among the sample of the 68 papers that we summarize in this systematic review) that analyse each internal mechanism, distributed in three panels depending on ownership structure (Panel A), board composition (Panel B) and corporate governance indices (Panel C). The papers are identified by numerical codes, from 1 to 68, following the list indicated in Appendix A.

\begin{tabular}{|c|c|c|}
\hline Corporate governance mechanisms & Papers & No. of papers \\
\hline Panel A: Ownership Structure & $\begin{array}{l}1,6,7,8,11,12,13,14,15,16,18,20,21,23,24,25,26,28,30,31,32,33,34,35 \\
36,37,38,41,42,43,45,47,48,51,52,53,55,56,57,58,59,61,62,63,64,65,66 \\
67,68\end{array}$ & 49 \\
\hline Institutional ownership & $\begin{array}{l}1,6,8,12,14,15,18,20,24,25,30,31,33,34,41,45,47,48,51,52,55,56,57,61,62 \\
63,65\end{array}$ & 27 \\
\hline State ownership & $13,15,21,23,25,26,28,37,38,43,45,51,52,58,65,67,68$ & 17 \\
\hline Insider ownership & $6,8,11,18,25,33,35,47,55,57,59,61,64,65,66$ & 15 \\
\hline Ownership concentration & $6,7,16,21,25,32,36,37,43,4853,58,62,67$ & 14 \\
\hline Foreign ownership & $23,26,28,36,37,42,58,64,68$ & 9 \\
\hline Family ownership and excess control rights & $8,15,43,51,52,62,65$ & 7 \\
\hline $\begin{array}{l}\text { Financial (bank) and non-financial (industry) } \\
\text { ownership }\end{array}$ & $8,21,45,51,52$ & 5 \\
\hline Panel B: Board Composition & $\begin{array}{l}1,4,5,6,9,10,12,13,14,18,19,20,21,23,25,29,30,31,33,36,39,44,46,48,49 \\
53,54,55,57,58,59,61,64,65,66\end{array}$ & 35 \\
\hline Board independence & $4,5,6,10,12,13,18,19,21,29,31,33,36,46,48,49,53,55,57,59,61,64,65,66$ & 24 \\
\hline Board size & $1,4,5,10,18,21,25,29,31,33,36,46,48,49,53,55,57,59,61,64,65$ & 21 \\
\hline CEO duality & $4,6,21,25,29,36,46,48,53,54,55,57,65$ & 13 \\
\hline Foreign directors & $5,9,23,36,58$ & 5 \\
\hline Female directors & $18,31,36,46$ & 4 \\
\hline $\begin{array}{l}\text { Board and/or CEO network and political } \\
\text { connections }\end{array}$ & $10,13,39,54$ & 4 \\
\hline Director tenure and managerial ability & $10,14,31,54$ & 4 \\
\hline CEO power (tenure, age, duality, etc.) & $18,44,49$ & 3 \\
\hline Additional board characteristics & $4,5,9,10,20,30,31,36,65,66$ & 10 \\
\hline Panel C: Corporate Governance Indices & $2,3,6,10,17,18,20,24,31,35,40,47,48,49,5060,62,66$ & 18 \\
\hline GIM index (Gompers et al., 2003) & $6,18,24,47$ & 4 \\
\hline Managerial power index (Bebchuk et al., 2009). & $10,20,31,35$ & 4 \\
\hline Self-constructed index of good governance & $3,17,50,60$ & 4 \\
\hline Other indices of good governance & $2,40,48,49,62,66$ & 6 \\
\hline
\end{tabular}

\section{Ownership structure and credit risk}

We find in Table 4, Panel A that ownership structure is by far the component of corporate governance that has been most analysed. ${ }^{3}$ In the following sub-sections, we carry out an in-depth analysis of each of these mechanisms in relation to their impact on credit risk, which is presented in Table 5, Panel A.

\subsection{Institutional ownership}

In most papers (23/27), institutional ownership is defined as the shares held by institutional investors, without providing a deeper definition of what an institutional investor is, and the empirical papers that do offer a clear definition do not agree on the type of investor that should be included in the institutional investor category (Barry et al., 2011; Liu and Yeh, 2018). In addition, Bhojraj and Sengupta (2003) and Cao et al. (2015) find differences between institutional ownership and institutional ownership concentration. Bhojraj and Sengupta (2003) show that while institutional ownership decreases credit risk, the percentage of shares held by the five largest institutional investors has an adverse effect, increasing credit risk. This may be due to the possible conflicts of interest that can appear in an organization when several blockholders coexist. However, Cao et al. (2015) find that institutional ownership increases credit risk, and that the number of institutional investors does not have any impact.

We are not able to explain any difference related to the institutional setting from the results of single-country papers, since most of the empirical papers are based on developed countries, especially the U.S. In this country the results differ with a positive (Bhojraj

\footnotetext{
${ }^{3} 49$ of the 68 papers reviewed in this paper (72\%) consider some of the mechanisms included in this category. The most studied mechanisms are institutional ownership (27 papers), followed by state ownership (17 papers), insider ownership (15 papers) and ownership concentration (14 papers). There are other papers that consider other components of the ownership structure, such as the ownership of foreign investors ( 9 papers), family ownership and excess control rights (7 papers), and financial versus non-financial shareholders (5 papers).
} 
Table 5

Internal corporate governance mechanisms and their effect on firms' credit risk. This table shows the effect on credit risk of each internal mechanism analysed in the literature, as well as the total number of papers (from among the sample of the 68 papers that we summarize in this systematic review) that find each effect. +, - and NS indicates an increase, decrease, and non-significant effect on the firm's credit risk, respectively. The different internal corporate governance mechanisms are distributed in three panels depending on ownership structure (Panel A), board composition (Panel B) and corporate governance indices (Panel C). The papers are identified by numerical codes, from 1 to 68, indicated in Appendix A.

\begin{tabular}{|c|c|c|c|}
\hline Corporate governance mechanisms & Effect & Papers & No. of papers \\
\hline \multicolumn{4}{|c|}{ Panel A: Ownership Structure } \\
\hline \multirow[t]{3}{*}{ Institutional ownership } & + & $1,8,12,14,18,20,30,31,33,48,56,57,61$ & 13 \\
\hline & NS & $18,30,41,47,51,52,55,62,65$ & 9 \\
\hline & - & $6,12,14,15,24,25,34,41,45,47,55,56,57,63,65$ & 15 \\
\hline \multirow[t]{3}{*}{ State ownership } & + & $13,15,21,23,26,28,37,58,68$ & 8 \\
\hline & NS & $21,23,25,52,65$ & 5 \\
\hline & - & $38,43,45,51,65,67$ & 7 \\
\hline \multirow[t]{3}{*}{ Insider ownership } & + & $8,11,18,25,47,55,57$ (inverted U), 59, 61, 66 & 10 \\
\hline & NS & $11,35,47,55,57,64$ & 6 \\
\hline & - & $6,11,25,33,35,55,61,65$ & 8 \\
\hline \multirow[t]{3}{*}{ Ownership concentration } & + & $6,7,16,21,25,32,36,48,67$ & 9 \\
\hline & NS & $21,37,48$ & 3 \\
\hline & - & $43,53,58,62$ & 4 \\
\hline \multirow[t]{3}{*}{ Foreign ownership } & + & $36,37,64$ & 3 \\
\hline & NS & $23,26,37$ & 3 \\
\hline & - & $23,28,42,58,68$ & 5 \\
\hline \multirow[t]{3}{*}{ Family ownership } & + & 15,62 & 2 \\
\hline & NS & $15,51,52,65$ & 4 \\
\hline & - & 8,65 & 2 \\
\hline \multirow[t]{3}{*}{ Excess control rights } & + & $43,51,52$ & 3 \\
\hline & NS & & 0 \\
\hline & - & 51 & 1 \\
\hline \multirow[t]{3}{*}{ Financial (bank) ownership } & + & 45 & 1 \\
\hline & NS & $45,51,52$ & 3 \\
\hline & - & 8,21 & 2 \\
\hline \multirow[t]{3}{*}{ Non-financial (industry) ownership } & + & 45 & 1 \\
\hline & NS & $8,45,51,52$ & 4 \\
\hline & - & 21 & 1 \\
\hline
\end{tabular}

Panel B: Board composition

\begin{tabular}{|c|c|c|c|}
\hline \multirow[t]{3}{*}{ Board independence } & + & $21,46,48,53,59,57,61$ & 7 \\
\hline & NS & $5,18,29,33,49,55,59,64,65$ & 9 \\
\hline & - & $4,5,6,10,12,13,19$ (U-shaped), 31, 36, 49, 55, 57, 66 & 13 \\
\hline \multirow[t]{3}{*}{ Board size } & + & $25,48,55,57,65$ & 5 \\
\hline & NS & $1,5,18,21,33,36,49,55,57,64$ & 10 \\
\hline & - & $4,10,21,29,31,46,53,55,59,61$ & 10 \\
\hline \multirow[t]{3}{*}{ CEO duality } & + & $6,36,46,48,53,54,55,57,65$ & 9 \\
\hline & NS & $4,21,25,55,57$ & 5 \\
\hline & - & 29 & 1 \\
\hline \multirow[t]{3}{*}{ Foreign directors } & + & & 0 \\
\hline & NS & 5,23 & 2 \\
\hline & - & $5,9,23,36,58$ & 5 \\
\hline \multirow[t]{3}{*}{ Female directors } & + & & 0 \\
\hline & NS & 31 & 1 \\
\hline & - & $18,36,46$ & 3 \\
\hline \multirow[t]{3}{*}{ Board and/or CEO network and political connections } & + & 13 & 1 \\
\hline & NS & & 0 \\
\hline & - & $10,39,54$ & 3 \\
\hline \multirow[t]{3}{*}{ Director tenure and Managerial ability } & + & 54 & 1 \\
\hline & NS & & 0 \\
\hline & - & $10,14,31$ & 3 \\
\hline \multirow[t]{3}{*}{ CEO power (tenure, age, duality, etc.). } & + & 44,49 & 2 \\
\hline & NS & 18,49 & 2 \\
\hline & - & & 0 \\
\hline
\end{tabular}

Panel C: Corporate Governance Indices

GIM index by Gompers et al. (2003)

$\begin{array}{ll}+ & 18 \\ \text { NS } & 24 \\ - & 6,24,47\end{array}$

1
1
3

(continued on next page) 
Table 5 (continued)

\begin{tabular}{lll}
\hline Corporate governance mechanisms & Effect & Papers \\
\hline Managerial power index by Bebchuk et al. (2009) & + & 35 \\
& NS & 10 \\
Self-constructed index of good governance & - & 20,31 \\
& + & 50,60 \\
Other indices of good governance & NS & $3,17,50,60$ \\
& - & 40,49 \\
4 & + & 49 \\
4
\end{tabular}

and Sengupta, 2003; Bonsall et al., 2017; Cao et al., 2015; Chen et al., 2017; Fields et al., 2012; Mili and Abid, 2016; Switzer and Wang, 2017; Upadhyay, 2015), non-significant (Cao et al., 2015; Li and Wang, 2016; Mansi et al., 2009) and negative effect (Ashbaugh-Skaife et al., 2006; Bhojraj and Sengupta, 2003; Bonsall et al., 2017; Cheng and Subramanyam, 2008; Ge et al., 2017; Li and Wang, 2016; Mansi et al., 2009; Switzer and Wang, 2017; Wang and Zhang, 2009) on credit risk. Therefore, there is a clear bias towards the U.S. setting, and the results are far from unanimous. In addition, one of the U.S.-country studies shows differences in the effect of control mechanisms on credit risk within the same paper. This is the case for Li and Wang (2016) which find that institutional ownership reduces the firm's credit risk only for companies with high G-index (low shareholders rights).

The lack of consensus on the U.S. setting leads us to question whether institutional owners should be treated as a heterogeneous group with different types of investors that exert opposing effects on credit risk. As an exception, there are two papers that, using a U.S. sample, consider this type of shareholder as a heterogeneous group, providing a distinction between types of institutional investors. Wang and Zhang (2009) differentiate between three types of institutional ownership based on their portfolio diversification and trading frequency, and their effect on credit risk. While transient investors (with high turnover and diversified positions) and the quasi-indexing group (with low turnover and high diversification) reduce credit risk, dedicated investors (with low turnover and high concentration) increase it. The authors explain this result as support for the information asymmetry hypothesis. This hypothesis states that transient investors, due to their high portfolio turnover, are more sensitive to stock liquidity, which leads them to concentrate on firms with tight bid-ask spreads and reduces the information asymmetry. This is opposed to the corporate governance hypothesis, which would not expect a decrease in credit risk with the increase in transient shareholders given that their diversified positions and short-term horizon reduce their monitoring function. Finally, there are also five non-U.S. single-country papers distributed in four different countries, China, Taiwan, Canada and Indonesia. Again, among them there is no consensus on the effect of institutional ownership on credit risk, but the number of studies is not big enough to reach a conclusion on what the effect is in a specific setting.

Among the multi-country sample papers, we draw attention to Liu and Yeh (2018), who split the sample between U.S. and nonU.S. companies, where the latter group includes South America, Europe, Asia and Australia. They find a negative effect of institutional ownership on credit risk for both samples. However, a different result is found using a multinational sample of 42 countries, where Ferreira and Matos (2012) conclude that when there is an institutional investor who is affiliated with the firm's lead creditor and holds shares in the firm, credit risk increases in the U.S., but the effect is not significant in the rest of the countries.

Beyond the U.S. setting, Switzer et al. (2018a) find that governance variables, including institutional ownership, have a greater impact on default risk for Asian firms in comparison to their European counterparts. Thus, they note that while institutional ownership decreases credit risk in a European context, this effect is sometimes non-significant for Asian countries. Following Eun et al. (2015), they attribute these results to cultural differences among countries. This contradicts the findings in Akwaa-Sekyi and Gene (2017) and Barry et al. (2011), who detect in a European sample an increasing effect of institutional ownership on credit risk.

Switzer and Wang (2017) also differentiate between long-term and short-term institutional investors based on their aggregate portfolio turnover and presents different theories that explain the effect of both types of institutional owners on credit risk. Regarding short-term investors, under the improved information environment hypothesis, these shareholders are expected to decrease credit risk due to their greater transparency and monitoring via "exit", which help to reduce credit spreads. Under the price pressure hypothesis, these shareholders would increase credit risk due to their myopic behaviour. On the other hand, Switzer and Wang (2017) summarize another two theories on the relationship between long-term institutional shareholders and credit risk. Under the shared benefit hypothesis, these investors are expected to decrease credit risk due to their monitoring role, reducing managerial opportunistic behaviour. Under the wealth transfer hypothesis, the opposing effect would be expected, since shareholders may engage in asset substitutions, debt overhang, adverse payout policies and takeovers. These actions lead to an increase in the agency cost of debt, which will increase a firm's credit risk. The authors find support for the first and fourth hypotheses, that is, short-term institutional investors reduce firms' credit risk, while long-term institutional owners increase it.

Therefore, more empirical papers should consider the heterogeneity of institutional investors before analysing their impact on credit risk. Differences based on the institutional setting could be better analysed in-depth in a second step.

\subsection{State ownership}

State ownership is defined as the shares held by the state, that is, by the government, which might be at a national and/or local level. If we analyse single-country papers, it is interesting that the positive effect of state ownership on credit risk only appears for 


\section{Table 6}

Summary table of conclusions. This table shows a summary of the main conclusions of the effect of each corporate governance mechanism on credit risk and the future lines of research to be developed in the future. There are two futures lines of research, common to all mechanisms, that do not appear in the table: the need to carry out more studies that explicitly analyse differences between financial and non-financial firms, and between the global financial crisis period and the non-crisis period.

\begin{tabular}{ccc}
\hline Mechanism & Main conclusions (effect of each mechanism on credit risk) \\
Panel A: Ownership Structure
\end{tabular}

Panel A: Ownership Structure

Institutional ownership Predominance of studies in the U.S. setting.

Lack of consensus in all settings.

Differences in credit risk based on the type of institutional

investor (portfolio diversification and trading frequency, aggregate portfolio turnover).

In the U.S., positive (negative) effect of long-term (shortterm) institutional investors on credit risk, but negative (positive) effect during the global financial crisis (Switzer and Wang, 2017).

State ownership

Insider ownership

Ownership concentration

Foreign ownership

Family ownership and excess control rights

Financial and non-financial ownership
State ownership increases credit risk in emerging countries where the interference of the state is high.

The positive effect seems to disappear (Borisova et al.,

2015) or diminish during economic downturns (Zhu and

Yang, 2016).

There is a clear difference between director and managerial ownership. Director ownership, rather than managerial ownership, increases credit risk.

Lack of consensus on the effect of director ownership in Asia.

Lack of consensus on the differences between financial and non-financial firms.

The negative effect of ownership concentration on credit risk is only found in Asian and European countries, which have highly concentrated ownership.

Lack of studies beyond the Asian context, and non-financial firms.

Positive effect in countries whose cultural peculiarities prevents the adaptation of foreign investors (such as Islamic countries, Japan or India).

Negative effect in China where foreign ownership is presented as an alternative to state ownership.

Positive effect of excess control rights.

Negative or non-significant effect of family ownership in European countries where the use of control chains is lower.

Lack of consensus in the Asian context.

Higher negative effect of family ownership during economic downturns.

Lack of consensus for both types of ownership.
Analysis of the heterogeneity of institutional investors. More empirical papers beyond the U.S. setting. More studies on financial companies and their differences in regulation with respect to non-financial firms that affect the nature of monitoring.

More studies for non-financial companies.

Analysis of the differences between director and managerial ownership.

More studies that look for differences among countries.

Analysis of the difference between ownership concentration and the number of blockholders, which may reflect conflicts among them.

More studies in countries different from the Asian setting and for non-financial firms.

Analysis of financial institutions in other emerging economies with restrictions for banks of foreign shareholdings, such as Brazil, Ethiopia, Malaysia, Mexico, Turkey, or Vietnam.

More studies that directly analyse the final outcome of the family risk-taking activities, measured by credit risk. Analysis of the differences based on the family business type: first versus second and subsequent generations.

Analysis of financial investor who also serves as the firm's creditor.

Analysis of the differences between non-financial investors from related sectors and those from non-related sectors. Analysis of non-financial firms.

Panel B: Board Composition

Board independence

CEO duality

Foreign directors

Board size
Lack of consensus in all settings.

Quadratic relationship between board independence and credit risk in U.S.

No consensus on the differences between financial and nonfinancial firms. Negative effect in most cases for the North American and U.K. context.

No consensus in the Asian and European context. No consensus on the differences between financial and nonfinancial firms.

Consensus on the positive effect.

No consensus on the differences between financial and nonfinancial firms.

In general, negative effect in developing and European countries.

Lower effect during the crisis period.
More analysis of the possible quadratic relationship between board independence and credit risk. More studies beyond the U.S. setting.

Analysis that explicitly compare different institutional settings.

More studies in the European context.

Analysis of the differences between countries with low and high entrenchment of managers.

Analysis of the differences between developing and

developed countries.

Studies for non-financial firms. 
Table 6 (continued)

\begin{tabular}{|c|c|c|}
\hline Mechanism & Main conclusions (effect of each mechanism on credit risk) & Future lines of research \\
\hline Female directors & Negative effect in US, UK and Asia context. & $\begin{array}{l}\text { Analysis of countries where female quotas are compulsory, } \\
\text { such as Norway, France, Italy, Belgium, Netherlands or } \\
\text { Germany. } \\
\text { Analysis of the differences between independent females } \\
\text { and non-independent females. }\end{array}$ \\
\hline $\begin{array}{l}\text { Director and/or CEO networks } \\
\text { and Political connections }\end{array}$ & $\begin{array}{l}\text { Negative effect of CEO network in the U.S. } \\
\text { No consensus on the effect of political connections in China } \\
\text { (positive) and Italy (negative) }\end{array}$ & $\begin{array}{l}\text { More studies for the U.S. and other settings that confirm } \\
\text { whether the benefits overcome the agency costs associated } \\
\text { with networking. } \\
\text { Comparison between developed and emerging countries, } \\
\text { where the access to external capital is more limited. } \\
\text { More studies for financial firms. }\end{array}$ \\
\hline $\begin{array}{l}\text { Director tenure and managerial } \\
\text { ability }\end{array}$ & $\begin{array}{l}\text { All studies from the U.S. } \\
\text { Negative effect of director tenure. } \\
\text { No consensus on the effect of managerial ability. }\end{array}$ & $\begin{array}{l}\text { Analysis of director tenure in countries with higher } \\
\text { entrenchment. } \\
\text { More studies for the U.S. and beyond. } \\
\text { Studies for financial firms. }\end{array}$ \\
\hline CEO power & $\begin{array}{l}\text { Positive or non-significant effect in the U.S. } \\
\text { Positive effect only during sovereign crisis period for a } \\
\text { multi-country sample. }\end{array}$ & $\begin{array}{l}\text { Analysis of more settings, with special emphasis on } \\
\text { emerging countries where powerful CEOs could help to } \\
\text { open up access to other markets, reducing credit risk. } \\
\text { Analysis of differences based on the definition of CEO } \\
\text { power. }\end{array}$ \\
\hline Additional board characteristics & $\begin{array}{l}\text { Negative effect of board expertise (measured by board } \\
\text { recruiting capability) in the U.S. and non-significant effect } \\
\text { for other measures in the U.S. and Europe. } \\
\text { Negative effect of the CEO when is the founder of a family } \\
\text { firm, in Asia. } \\
\text { Negative effect of audit committees, compensation, } \\
\text { governance and nomination committees or specific risk } \\
\text { committees in the U.S. }\end{array}$ & $\begin{array}{l}\text { Given that there is only one paper for each mechanism, } \\
\text { more papers that analyse: board expertise, the presence of } \\
\text { state or institutional directors, the existence of staggered } \\
\text { boards, the presence of family CEOs, the existence of } \\
\text { different committees, or the relationship between common } \\
\text { members on board and lead arranger bank. }\end{array}$ \\
\hline \multicolumn{3}{|c|}{ Panel C: Corporate Governance Indices } \\
\hline $\begin{array}{l}\text { GIM index by Gompers et al. } \\
\qquad \text { (2003) } \\
\text { Managerial power index by } \\
\text { Bebchuk et al. (2009) } \\
\text { Self-constructed index of good } \\
\text { governance } \\
\text { Other indexes of good governance }\end{array}$ & $\begin{array}{l}\text { No consensus on the effect on credit risk for any of the } \\
\text { indices. } \\
\text { Most papers analyse the U.S. }\end{array}$ & $\begin{array}{l}\text { More papers that analyse the U.S. and other countries } \\
\text { beyond the U.S., especially less developed and emerging } \\
\text { countries. }\end{array}$ \\
\hline
\end{tabular}

companies from emerging countries such as China, India, Philippines or Egypt. This is in line with Cornett et al. (2010), who detect an increasing effect of state ownership on credit risk for their multi-country sample of East Asian firms; or Chen and Lin (2016), who, for a sample of financial institutions from 43 countries, observe that state ownership has no impact on credit risk for developed countries, but increases it for developing ones. In multinational European samples the effect is found to be non-significant (Saghi-Zedek and Tarazi, 2015) or negative (Iannotta et al., 2013; Saghi-Zedek, 2016). Multinational samples that consider both settings, Asia and Europe, obtain mixed results: positive (Borisova et al., 2015) and negative (Lin et al., 2011; Liu and Yeh, 2018). ${ }^{4}$

Therefore, it seems that differences in the role played by state ownership in credit risk are due to, among others, the institutional setting. These results are in line with the two arguments presented by Borisova et al. (2015). On the one hand, the state has fewer monitoring incentives and skills to control risk-taking by managers who take advantage of the public funds that would be used in the event of default. Lack of monitoring of this moral hazard problem would increase the firm's credit risk. This effect is found in emerging countries where state interference is larger, and the lack of efficient resource allocation and monitoring increase credit risk. On the other hand, state-owned companies obtain financing at lower costs given their implicit guarantee, which lowers the perceived probability of default. This advantage appears in developed countries, where the lower interference of the government prevents the potential disadvantages and allows the potential benefits to be enhanced.

\footnotetext{
${ }^{4}$ On the one hand, Borisova et al. (2015) find that, under normal economic conditions, government ownership increases the cost of debt. On the other hand Lin et al. (2011) find that the cost of debt is reduced with increasing state ownership, in line with the results found by Liu and Yeh (2018) who show that the proportion of shares held by the state improves the Standard and Poor's credit rating of acquirer financial institutions.
} 


\subsection{Insider ownership}

Insider ownership refers to the shares held by investors who are not internally involved in the organization. ${ }^{5}$ We observe, in general, that companies from the U.S. (Berger et al., 2016; Cao et al., 2015; Mansi et al., 2009; Upadhyay, 2015; Zagorchev and Gao, 2015), Europe (Barry et al., 2011) Japan (Tanaka, 2016) and Canada (Switzer et al., 2018b), increase credit risk with larger insider ownership, especially if this is director ownership, rather than managerial ownership. As explained by Chiang et al. (2015), director ownership is the percentage of shares held by the directors of the board, and managerial ownership is the percentage of shares held by the CEO and the executive directors. They find for a Taiwanese sample that while director ownership increases default risk, managerial ownership decreases it. This result is in line with Gao and Lin (2018) who also observe managerial ownership reducing credit risk in China, but not with Yen et al. (2015), who find a decreasing effect of director ownership on credit risk in Taiwan.

In addition, Berger et al. (2016) takes apart the effect on credit risk of the shares held by non-executive directors of the board, the CEO, top-level management, and low-level management. Overall, they find that while non-executive directors and both types of managers increase credit risk, CEO ownership reduces it. These results support the idea of moral hazard incentives for managers, which increase the probability of the business to fail.

The results indicate a clear difference between director and managerial ownership, which result in differences in their effect on credit risk. We would need more studies on this relationship in other countries that differentiate between managerial and director ownership to provide stronger conclusions and analyse possible differences among countries.

\subsection{Ownership concentration}

The concentration of ownership can be measured in different ways. Some papers use the shares held by the main or the firm's largest shareholders (Brogaard et al., 2017; Chen and Lin, 2016; Chiang et al., 2015; Froneberg et al., 2016; Haque and Shahid, 2016; Lin et al., 2011; Shu et al., 2015; Tacneng, 2015; Utama et al., 2016), the number of blockholders (Ashbaugh-Skaife et al., 2006; Grassa, 2016) or dummy variables to represent the presence of a shareholder with a minimum ownership threshold (Auvray and Brossard, 2012; Mili and Abid, 2016; Zheng et al., 2017). We need to be cautious because the number of shareholders with a significant participation in the business may not only reflect the ownership concentration, but also possible conflicts between several blockholders.

The effect of ownership concentration on credit risk is clearly related to the institutional setting. The work of La Porta et al. (1999) has become an important reference in corporate ownership with its look at the ownership of the 20 largest publicly traded companies in the 27 richest economies of the world. These authors find that typical large firms are owned by an ultimate owner, usually a family firm, which contradicts the work of Berle and Means (1932), where most companies were supposed to be widely held, that is, dispersed across a large number of small public shareholders. Dispersion of ownership will be potentially related to the degree of minority shareholder protection (La Porta et al., 1999). Thus, legal rules affect the trade-off between the benefits and the costs of separating ownership and management. As a consequence, the credit risk of companies coming from different legal environments cannot be compared without considering this issue. Thus, companies can be catalogued into two different groups, one pertaining to countries with poor minority shareholder protection, also known as civil law countries (La Porta et al., 1999) characterized by a diffuse capitalism (Morck et al., 2005), and the other group associated with countries with high minority shareholder protection or common law countries where oligarchic capitalism is more usual.

It is interesting that the negative effect of ownership concentration on credit risk is only found in Asian and European countries that have highly concentrated ownership (Lin et al., 2011; Shu et al., 2015; Tacneng, 2015; Utama et al., 2016). This means that the potential expropriation in the form of higher risk (Shleifer and Vishny, 1997) disappears given their undiversified portfolios, which leads these shareholders to be more conservative and increase their monitoring incentives (Shleifer and Vishny, 1986). This conservative attitude does not appear with low levels of diffuse ownership.

\subsection{Foreign ownership}

Foreign ownership is defined as the percentage of shares held by foreign investors (ElBannan, 2015; Grassa, 2016; Haque and Shahid, 2016; Lim and Mali, 2018; Tacneng, 2015; Yeh, 2017), although some papers do not consider their shares, but just their presence in the business (Cheng et al., 2016; Cornett et al., 2010; Zhu and Yang, 2016). All empirical papers that analyse the effect of foreign ownership on credit risk look at Asian samples, except for ElBannan (2015), who uses Egyptian companies.

On the one hand, Grassa (2016) finds an increase in credit risk with foreign ownership in their sample composed of firms from Islamic countries. This work emphasizes the key role that Shariah (Islamic law) plays in the governance of financial institutions of those countries where the Islamic moral code serves as a corporate governance mechanism that prevents the management from behaving unethically. Therefore, the positive effect of foreign ownership on credit risk may be due to the conflicts that appear when different cultures are mixed. A similar pattern is found in Japan (Yeh, 2017) and India (Haque and Shahid, 2016), where their

\footnotetext{
${ }^{5}$ Some papers consider insiders as managers (Gao and Lin, 2018; Ghouma, 2017; Tanaka, 2016), directors of the board (Cao et al., 2015; Yen et al., 2015; Zagorchev and Gao, 2015), or both (Ashbaugh-Skaife et al., 2006; Barry et al., 2011). Yeh, 2017 provides a more specific definition by considering as insider ownership only the shares of top management. Others do not specify what an insider is (Mansi et al., 2009; Switzer et al., 2018b).
} 
cultural peculiarities prevent the adaptation of foreign investors. Yeh (2017), for instance, argues that foreign investors push firms to undertake riskier activities with the goal of obtaining higher returns.

However, we find the opposite effect in China (Cheng et al., 2016; Zhu and Yang, 2016), where foreign ownership is seen as an alternative to state ownership, bringing new skills that organizations lack and providing greater diversification that helps to reduce credit risk. Negative relationships also appear in the Philippines (Tacneng, 2015), Egypt (ElBannan, 2015) and Korea (Lim and Mali, 2018). Therefore, foreign investors reduce credit risk in countries where foreign ownership is contrasted against state ownership, providing businesses with improvements in their financial services, better skills and technology, supervision and improving access to international capital markets. In addition, Cheng et al. (2016) find that the success of foreign investors in reducing credit risk depends on their interplay with other shareholders. They find that the negative effect on credit risk of foreign ownership and directors appointed by these foreign investors is lower when firms are owned by the state. The authors attribute this finding to the lack of ability of foreign shareholders to change the risk-taking behaviour of firms when the state has significant shareholdings.

It would be interesting to analyse the role played by foreign investors in financial institutions in other emerging economies where restrictions exist on banks of foreign shareholdings (Karabay, 2010). While Tacneng (2015) analyses companies in the Philippines where these restrictions are found, other countries that also face these limitations could be studied, such as Brazil, Ethiopia, Malaysia, Mexico, Turkey, or Vietnam.

\subsection{Family ownership and excess control rights}

In the literature about the risk-taking behaviour of family firms, there seems to be a consensus on the conservative attitude of family owners (Hoskisson et al., 2017). However, we do not observe a consensus on their direct effect on credit risk, which might be related to, among other factors, the type of family business. The number of empirical papers that directly study the effect of family ownership (Barry et al., 2011; Borisova et al., 2015; Yen et al., 2015) or family presence (Saghi-Zedek, 2016; Saghi-Zedek and Tarazi, 2015; Utama et al., 2016) on credit risk is very limited, despite the predominance of family businesses around the world (Morck et al., 2005). Additionally, not many papers relate the divergence between cash flow and voting rights with the firm's credit risk (Lin et al., 2011; Saghi-Zedek, 2016; Saghi-Zedek and Tarazi, 2015), and, overall, they find a positive association between them. Since excess control rights is one of the mechanisms used by families to boost their entrenchment, those family businesses that use this type of ownership structure will likely positively impact credit risk.

In European countries where the use of control chains is less than in the Asian context, family ownership decreases (Barry et al., 2011) or has no effect (Saghi-Zedek, 2016; Saghi-Zedek and Tarazi, 2015) on credit risk. In addition, in unreported results, the work by Barry et al. (2011) explains that family ownership reduces credit risk only for those European countries with a relative low degree of shareholder protection, since in countries with a higher degree of shareholder protection large undiversified shareholders, such as institutional investors, are better able to influence managers and family owners to take more risk. Another explanation could be related to the conflicts that appear with the presence of fractional ownership (Schulze, et al., 2001), when different significant investors with opposing interests coexist in the organization, creating conflicts that may affect the firm's credit risk. This argument is in line with the findings obtained by Cremers et al. (2007), which show that the reduction in credit risk is lower when the number of institutional blockholders increases.

In the Asian context, we find a positive and a negative effect in Indonesian and Taiwanese firms, respectively. Therefore, more studies would be needed to develop stronger conclusions, and should also consider whether the family is run by the first or subsequent generations or whether the founder is involved in the business. We could expect that the significant presence of various family owners in firms creates conflicts between family members (Blumentritt et al., 2013), increasing the probability of the business failing. In addition, companies where the founder is present may have an entrepreneurial talent which is lacking in old family-owned firms (Anderson and Reeb, 2003). As Villalonga and Amit (2006) find in the case of firm performance, it can be expected as well that family firms controlled or run by the founder exhibit different levels of credit risk as compared with those in subsequent generations.

\subsection{Financial (bank) ownership versus non-financial (industry) ownership}

As we can see in Table 4, there are only five papers that empirically study the effect of financial and non-financial ownership on credit risk. These papers do not reach a unanimous conclusion on the effect of financial investors on credit risk. In European companies, Saghi-Zedek (2016) and Saghi-Zedek and Tarazi (2015) find no effect of these investors on credit risk, although Barry et al. (2011) show a negative impact. It would be interesting to know whether the financial investor also serves as the firm's creditor. If this is the case, the results are in line with the idea of financial institutions being more risk averse and being providers of guarantees, which reduces credit risk. This negative impact is also supported by the multi-country sample in Chen and Lin (2016), but not in Liu and Yeh (2018), who observe a positive or non-significant effect of financial ownership.

There is no consensus either on the effect of non-financial ownership on credit risk, with positive (Liu and Yeh, 2018), negative (Barry et al., 2011; Chen and Lin, 2016) and non-significant (Liu and Yeh, 2018; Saghi-Zedek, 2016; Saghi-Zedek and Tarazi, 2015) effects found. There may be several explanations for this lack of consensus. First, industry ownership is heterogeneous, and thus it may not be the same if the non-financial institution is from the same sector as the company it invests in, rather than from a different

\footnotetext{
${ }^{6}$ Positive for the case of U.S. companies and those from countries with well-enforced regulation, and non-significant for non-U.S. companies and those from countries with poor-enforced regulation
} 
sector. On the one hand, it could be argued that a sector-related investor will offer greater knowledge to the company it invests in, therefore, reducing credit risk. On the other hand, another theory would establish that non-related sector investors, rather than related ones, reduce credit risk since they can spread the range of knowledge. Therefore, the effect of industry ownership and the differences between related and non-related investors remains an open empirical question. Second, most of these papers analyse the presence of financial and non-financial investors (Chen and Lin, 2016; Liu and Yeh, 2018; Saghi-Zedek, 2016; Saghi-Zedek and Tarazi, 2015), and only one studies the percentage of shares they own in the business (Barry et al., 2011). Since the number of shares owned in the business can be a proxy of the degree of the investor's commitment in the company, we should consider not only the type of investor, but also their ownership concentration to properly understand how they contribute to the firm's credit risk. Third, the lack of significance may be due to the existence of an indirect impact of this type of investor on credit risk. For instance, SaghiZedek (2016) shows that while the direct impact of ownership type is non-significant, there exists an indirect impact through the firm's diversification strategy. Thus, diversification reduces a firm's risk when there is a significant presence of financial, nonfinancial and institutional investors, and increases credit risk with the presence of significant family owners or with the lack of a controlling owner.

To summarize, conclusions on the effect of non-financial investors are more difficult given their heterogenous nature. Deeper analyses would help us to understand this relationship before studying the possible effect of the institutional setting.

\section{Board composition and credit risk}

We observe in Table 4, Panel B that $51 \%$ of the papers reviewed in this study (35/68) consider mechanisms related to board composition. ${ }^{7}$ In the following sub-sections, we carry out an in-depth analysis of each of these mechanisms in relation to their impact on credit risk, as presented in Table 5, Panel B.

\subsection{Board independence}

Overall, board independence is measured by the percentage of independent directors on the board, meaning non-executive directors who do not hold a management position in the firm. Although board independence is assumed to be a sign of good corporate governance, its effect on credit risk is mixed. Most studies are based on the U.S., and along with other countries with diffuse ownership such as Canada and U.K., positive (Lu and Boateng, 2018; Mili and Abid, 2016; Switzer et al., 2018b; Upadhyay, 2015) and negative effects (Ames et al., 2018; Ashbaugh-Skaife et al., 2006; Benson et al., 2018; Bhojraj and Sengupta, 2003; Fields et al., 2012; Switzer et al., 2018b; Zagorchev and Gao, 2015) of board independence on credit risk are found. This mixed evidence in this specific setting can be explained by Chen (2014) who finds a quadratic relationship between board independence and credit risk in the U.S. On the one hand, this paper shows that for lower levels of independence credit risk is reduced, in line with a shareholder perspective, since directors that come from outside the business will be better able to fulfil their role of monitoring the managers, thereby reducing credit risk. On the other hand, for higher levels of board independence credit risk increases, in line with a debtholder perspective, since independent boards that fight for shareholders' rights at the expense of creditors can increase the agency cost of debt, increasing the firm's credit risk given their risk-taking incentives. In addition, they may lack specific knowledge about the firm they serve on.

For the European context, Andries and Brown (2017) find that during the financial crisis, board independence decreased credit risk, while the effect is not significant for the rest of the period. Also, for Islamic Asian countries (Grassa, 2016) and China (Boateng et al., 2019) board independence is found to reduce credit risk. Thus, the benefits associated with higher monitoring in countries where shareholder entrenchment is higher outweigh the drawbacks. These results are in line with Switzer et al. (2018a) who, overall, find a negative effect for their European and Asian sample. However, in Japan (Tanaka, 2016) and Taiwan (Shu et al., 2015) the association between board independence and credit risk is positive.

Overall, there is not a clear pattern on the role played by independent directors on the board in terms of credit risk. More studies are needed, especially those beyond the U.S. setting, considering the possible non-linear effects and the crisis period.

\subsection{Board size}

Board size is defined as the number of directors on the board. In the North American and U.K. context, most papers find a reducing effect on credit risk with larger boards (Ames et al., 2018; Benson et al., 2018; Fields et al., 2012; Lu and Boateng, 2018; Upadhyay, 2015) as opposed to the finding by Mili and Abid (2016) and Switzer et al. (2018b). Results are more mixed in the Asian context, where some authors observe a positive effect (Chiang et al., 2015; Yen et al., 2015) and others a negative effect (Elhaj et al., 2018;

\footnotetext{
${ }^{7}$ Most of these studies that analyse the relationship between credit risk and board composition include board independence (24 papers), size (21 papers) and CEO duality (13 papers) significantly more than other board characteristics. Few papers analyse the association between credit risk and foreign directors ( 5 papers), female directors (4 papers), political connections and board or CEO networks (4 papers), director tenure and managerial ability (4 papers), and CEO power ( 3 papers). Additionally, there are some papers that include as determinants of the firm's credit risk other board characteristics not covered so far (such as board experience, the presence of state or institutional directors or the existence of specific risk committees, among others). However, it should be noted that each of them is analysed in just one paper. For this reason, in Table 4 we group these 10 papers under the title of "Additional board characteristics", while in Table 5 they are not presented in order to reduce space.
} 
Shu et al., 2015; Tanaka, 2016) and a non-significant effect in the context of Islamic countries (Grassa, 2016) and China (Gao and Lin, 2018). In European countries, the effect is not significant either (Akwaa-Sekyi and Gene, 2017; Andries and Brown, 2017). This result contradicts that detected by Switzer et al. (2018a), who compare the effect of board size on credit risk for Asian and European companies and find that the effect is positive for the European sample, and negative for the Asian context. Chen and Lin (2016) also find that board size has no impact for developed economies but, reduces credit risk for developing countries.

Therefore, the results are mixed in all settings and there is no a consensus on the role of board size on credit risk. On the one hand, from a resource dependence perspective (Pfeffer and Salancik, 1978), larger boards would reduce credit risk given the greater availability of individuals with different expertise and resources that can help the firm to increase managerial ability. On the other hand, from an agency point of view, larger boards would be expected to increase default risk given the potential internal problems that appear when directors face problems of communication and coordination (Jensen, 1993) that result in delays in decisionmaking.

Given the mixed evidence that exists, more empirical papers that explicitly compare different institutional settings are needed.

\subsection{CEO duality}

CEO duality occurs when the roles of CEO and chairman are in the hands of the same person. Although some papers do not find any significant effect, overall there seems to be a consensus on the positive relationship between CEO duality and credit risk for countries with widely held ownership, such as Canada, U.S. and U.K., and Asian countries, with the exception of Elhaj et al. (2018), who find a negative effect. These results are in line with the agency theory perspective, where reductions in monitoring (Chen and AlNajjar, 2012) and excessive power concentrated in one person who can expropriate other shareholders (Lewellyn and Muller-Kahle, 2012), increase the firm's credit risk.

The limited number of empirical papers that analyse this relationship in the European context is curious. One of them is Switzer et al. (2018a), who include European companies in their sample and find that while in Europe CEO duality does not affect a firm's credit risk, in Asian companies CEO duality increases it. This may suggest that companies from Asian contexts, where managers are more likely to be entrenched, should highlight the importance of board structures where the CEO is not the same person as the chairman.

\subsection{Other board characteristics}

We group in this subsection the rest of the board characteristics analysed in the literature (such as foreign directors or female directors, among others) since the number of papers that are analysed is quite small and therefore the findings on the effect on credit risk are not robust. Therefore, the main conclusion for the following mechanisms is that more papers are needed.

\subsubsection{Foreign directors}

One way to measure the diversity of the board is to consider the number of foreign directors who hold a board position. All papers show a non-significant (Andries and Brown, 2017; Cheng et al., 2016) or negative effect (Andries and Brown, 2017; Ben Saada, 2018; Cheng et al., 2016; Grassa, 2016; Tacneng, 2015) of foreign directors on credit risk. ${ }^{8}$ Despite the presence of institutional investors and their effect on credit risk being mixed, the effect of foreign directors on the board is clearer. The empirical papers show that having foreign directors on the board helps to reduce credit risk in Tunisia (Ben Saada, 2018), Philippines (Tacneng, 2015), China (Cheng et al., 2016), Europe (Andries and Brown, 2017) and Islamic countries (Grassa, 2016). Therefore, the access to international capital markets brought by these directors, help the firm to decrease their credit risk. However, their relationship with other stakeholders is also important, as highlighted by Cheng et al. (2016), who find that the negative effect is lower if the firm is owned by the state.

Therefore, these papers reach a consensus on the benefits of foreign directors in developing and European countries. A future line of research should study whether the effect is different for developing countries than for developed ones.

\subsubsection{Female directors}

Gender diversity is measured by the percentage of females that serve on the board of directors. Cao et al. (2015); Grassa (2016) and, Lu and Boateng (2018) find a negative effect on credit risk, as expected by Vandergrift and Brown (2005), who explain that women are more risk averse than men, which translates into more conservative financial decisions. The results are also in line with the idea that their presence enriches the information and debate on decision-making (Francoeur et al., 2008) and improves managerial monitoring, which consequently impacts on credit risk.

These studies, which focus on the context of the U.S., U.K. and Asia, could be complemented by other institutional settings. We wonder whether in countries where female quotas are compulsory, such as Norway, France, Italy, Belgium, Netherlands or Germany, the effect is the same in comparison with other countries where the presence of females is only recommended. In addition, the presence of women on boards is very limited, and it would also be interesting to analyse differences between independent female

\footnotetext{
${ }^{8}$ It should be noted that Andries and Brown (2017) conclude that the effect is non-significant outside the crisis period and negative during the crisis period. For its part, Cheng et al. (2016) find a non-significant and negative effect when credit risk is measured by the z-score and nonperforming loans, respectively.
} 
directors and non-independent female directors, that is, women who are affiliated with the business or the founding family. As Poletti-Hughes and Briano-Turrent (2019) show, the roles played by independent and family-related female directors differs given their different degree of involvement in the family objectives.

\subsubsection{Board/CEO networks and political connections}

Benson et al. (2018) and Skousen et al. (2018) find, in the U.S. setting, a negative association between credit risk and director and CEO networks, respectively. Larger director networks help to increase the perceived trustworthiness and reputation, which allows for lower information asymmetry. In addition, directors with large and influential networks increase their monitoring and advising role given their greater experience and expertise. In terms of the networks of CEOs, they reduce credit risk if their networks grant them more access to private information that leads to better decisions.

In any case, more empirical papers are needed to check the robustness of this negative effect, not only in the case of the U.S. but also by extending the analysis to other developed countries. This involves confirming whether the benefits outweigh the agency costs associated with networking. Board members with larger networks could increase credit risk, given that they are busy directors and may not be able to provide effective monitoring and advising. In addition, it is possible that CEOs with more extensive networks become more powerful, leading to their entrenchment. They may also receive more information on earnings management practices and tax avoidance, increasing credit risk. Furthermore, it would be interesting to know whether this negative effect is stronger in emerging countries, where the access to external capital is more limited.

Another interesting line of research is the effect of politically connected board members on credit risk. We find two papers with opposite effects. Boateng et al. (2019) find that, in China, boards that are politically connected, due to the appointment of the CEO by the government, implement policies favourable to the state that eventually increase the firm's credit risk. However, in an Italian context, Infante and Piazza (2014) show that the presence on the board of a member of a political body decreases credit risk in the form of lower cost of debt. This finding shows that preferential treatment is linked to political influence. More empirical papers are needed to test whether political connections increase a firm's access to finance and reduce credit risk, or whether they increase credit risk by favouring social goals over company goals. We might expect, in line with these results, that in countries where state interference in companies is higher, political connections are driven by the government's goals rather than corporate objectives.

\subsubsection{Director tenure and managerial ability}

Director tenure is a measure that can be used to proxy the board's average level of experience. The greater the number of years that directors have served on the board, the greater their experience. The impact on credit risk of the years that on average the directors have served on the board has only been studied in the U.S., finding a negative effect (Benson et al., 2018; Fields et al., 2012). The number of years may be indicative of the board's experience, but also of the board's entrenchment. Whether this negative effect remains in other emerging economies or in countries with high ownership concentration, is still an open question.

Regarding the skills offered by managers, Bonsall et al. (2017) and Skousen et al. (2018) use the measure of managerial ability constructed by Demerjian et al. (2012), which is built based on the efficiency of managers relative to their industry peers in transforming corporate resources to revenues. Despite both papers using a U.S. sample, they find opposite results. While Bonsall et al. (2017) observe a decrease in credit risk with higher managerial ability, the effect is positive in Skousen et al. (2018). We call for further research in this area in the U.S. and other institutional settings.

\subsubsection{CEO power}

In the U.S. context, Cao et al. (2015) find no significant effect on credit risk, while Liu and Jiraporn (2010) show a positive effect. For a multi-country sample (which includes countries from North America, South America, Europe, Asia and Australia) Mollah and Liljeblom (2016) find that more powerful CEOs increase credit risk, but only during the sovereign debt crisis. The results are in line with the idea of greater entrenchment when the CEO becomes more powerful, since more powerful CEOs have access to more competitive compensation contracts, which in turn entails greater risk taking, such as being involved in riskier lending practices (Lewellyn and Muller-Kahle, 2012).

Nevertheless, more empirical papers are needed to verify whether powerful CEOs indeed become entrenched managers, which leads to higher credit risk. In contrast to the previous argument, it may be possible that the power of the CEO allows them to control and influence the decisions of the board (Fama and Jensen, 1983; Adams et al., 2005) and become risk averse, which leads them to participate in less risky activities, especially during crises, and hence CEO power would be related with lower credit risk (May, 1995; Pathan, 2009). It is also possible that the effect depends on the firm's sector, and also the institutional setting. For instance, in emerging countries, powerful CEOs could help to open access to other markets, thereby reducing credit risk. In addition, it should be noted that the findings observed in the literature may be conditional on the alternative definitions of CEO power used. ${ }^{9}$

\footnotetext{
${ }^{9}$ Based on a sample of global banks, Mollah and Liljeblom (2016) construct an index that aims to represent the degree of power that the CEO can exercise in the business, in terms of influence, experience and expertise. This index is based on six factors: if the CEO is also the chairman, if the CEO is internally recruited, if the CEO's age is older than the median, if the CEO's tenure is longer than the median, if the CEO has more banking experience than the median, and if the CEO's academic qualifications are also greater than the median. Other papers use as proxies of CEO power only the number of years the CEO has served on the board (Cao et al., 2015) or the relative total compensation of the CEO as compared with the topfive executives (Liu and Jiraporn, 2010).
} 


\subsubsection{Additional board characteristics}

There are some papers that include as determinants of the firm's credit risk other board characteristics not covered so far. It is important to note that although we proceed to present the existing evidence regarding these additional characteristics, we must be careful when drawing conclusions, as it is necessary to have more empirical works to determine the impact of these characteristics on credit risk, given that each of them is analysed in just one paper. There is a need for further research that takes into account these board characteristics and analyses their role, as corporate governance mechanisms, in reducing credit risk.

There are some papers that use various characteristics that could serve to represent the expertise level of the board, such as the number of directors who serve on other boards (Fields et al., 2012), the number of expert members on the board (Andries and Brown, 2017) or the board's recruiting capability (Chen et al., 2017). We would expect that boards with more expertise will be better able to take favourable decisions for the company and exercise greater monitoring, thereby reducing credit risk. However, the first two papers do not find a significant effect, and only Chen et al. (2017) find this negative association. In addition, Benson et al. (2018) use as a measure of board experience the average age of directors, but do not find any impact on credit risk.

The presence of state or institutional directors does not have an impact on credit risk (Ben Saada, 2018), nor do staggered boards (Zagorchev and Gao, 2015). In addition, while the presence of a family member who serves as the CEO increases credit risk (Yen et al., 2015), when the CEO is the founder, credit risk decreases (Grassa, 2016). This is in line with Villalonga and Amit (2006), who find differences in firm performance between family firms run by the founder and those from other generations.

There also seems to be a negative association between credit risk and the existence of audit committees or compensation, governance and nomination committees (Zagorchev and Gao, 2015), or even specific risk committees (Ames et al., 2018), which is in line with the monitoring function they exercise. In addition, Ferreira and Matos (2012) analyse the effect on credit risk if there is at least one board member common to both the firm and the lead arranger bank. The results show a positive and negative effect based on the time period considered, which will be explained in subsection 6.2.

\section{Balance of power between stakeholders and managers (Corporate Governance Indexes)}

Of the three governance components that we cover in this review, the one related to the balance of power between stakeholders and managers is the least developed in the literature. ${ }^{10}$ The power that managers exert on stakeholders has been measured in the literature through various corporate governance indices, where strong managerial power is assumed to decrease good corporate governance, which would lead to an increase in credit risk. However, regardless of the type of index used, there is no consensus in the literature in this regard.

There are five papers that include the GIM-index by Gompers et al. (2003) as a proxy of the power-sharing relationship between shareholders and managers. The index is constructed by the summation of 24 anti-takeover provisions classified into five categories that represent management power ${ }^{11}$, so that higher values of the index represent weaker shareholder rights and greater management power, where shareholders have less of a voice in the appointment and replacement of managers and are therefore less able to punish management actions. Cao et al. (2015) find a positive relationship between the index and credit risk, that is, lower shareholder protection increases the firm's credit risk. However, Ashbaugh-Skaife et al. (2006); Cheng and Subramanyam (2008) and Mansi et al. (2009) find the opposite effect: lower values of the index, that is, greater shareholders rights, increase credit risk.

Other papers include as a corporate governance index the managerial power index by Bebchuk et al. (2009), which includes six of the 24 provisions considered by Gompers et al. (2003) to be the most important in describing shareholder protection. ${ }^{12}$ Also in this case, higher values of the index represent weaker shareholder protection and stronger entrenched managers, and again the effect on credit risk is varied. While Chen et al. (2017) and Fields et al. (2012) find a negative effect on credit risk, Benson et al. (2018) do not find any effect, and Ghouma (2017) concludes that the effect is positive. Other papers use self-constructed corporate governance indices (Ali et al., 2018; Byun, 2007; Safiullah and Shamsuddin, 2018; Tarchouna et al., 2017), or use other good corporate governance indices (Alali et al., 2012; Jiraporn et al., 2013; Mili and Abid, 2016; Mollah and Liljeblom, 2016; Utama et al., 2016; Zagorchev and Gao, 2015), but again there is no consensus on whether what they consider as better governance increases or reduces credit risk. $^{13}$

Although it is somewhat surprising that many papers find a positive association between "good governance" and credit risk, what

\footnotetext{
${ }^{10}$ Only 18 of the 68 papers that we summarize in this systematic review (26\%) consider alternative corporate governance indexes to analyse their impact on credit risk and, in addition, most of them do so in a somewhat superficial way since the main focus of these papers was not the study of the index, but the ownership structure and/or board mechanisms. Only six papers exclusively analyse the role of corporate governance indices (Alali et al., 2012; Ali et al., 2018; Byun, 2007; Jiraporn et al., 2013; Safiullah and Shamsuddin, 2018; Tarchouna et al., 2017) on credit risk.

${ }^{11}$ More specifically, the five categories are: tactics for delaying hostile bids, voting rights, director/officer protection, other takeover defenses, and state takeover laws.

${ }^{12}$ In particular, they include staggered boards, supermajority requirements for mergers, supermajority requirements for charter amendments, limits to shareholders amendments of the bylaws, poison pills and golden parachutes.

${ }^{13}$ For instance, Safiullah and Shamsuddin (2018) and Tarchouna et al. (2017) show that the corporate governance index has a positive (negative) effect for large (small) U.S. banks, while Byun (2007) and Ali et al. (2018) observe a negative effect for a sample of non-financial firms in Korea and Australia, respectively. Also, Jiraporn et al. (2013) find a positive relationship for U.S. companies, although the opposite effect is found by other papers that also analyse the U.S. setting (Alali et al., 2012; Mili and Abid, 2016; Zagorchev and Gao, 2015). This negative effect is also seen in a sample of Indonesian firms (Utama et al., 2016). Finally, Mollah and Liljeblom (2016) find a positive or non-significant effect of corporate governance on credit risk, based on the governance index used.
} 
may be behind this result is the potential wealth transfer from bondholders to shareholders that occurs when shareholders become more powerful. Thus, this finding lends support to the bondholder's perspective, which suggests that corporate governance practices that align with shareholders' interests may be detrimental to debtholders, increasing the conflict between shareholders and debtholders since it may result in riskier policies at the expense of creditors, and, therefore, increase the agency cost of debt and credit risk. In line with these results, and as opposed to Ali et al. (2018), who advocate for the use of indices that consider the firm's overall corporate governance quality, Switzer et al. (2018b) criticise the use of indices and state that they represent governance quality from the perspective of shareholders, but not debtholders. In the same manner, the use of an index from a creditor perspective would be also inadequate. Therefore, they suggest the use of individual corporate governance mechanisms and their interaction effect that tests their substitutivity or complementarity.

In addition, there is a clear bias towards the use of U.S. samples, with the exception of Byun (2007); Ali et al. (2018) and Utama et al. (2016), who use a Korean, Australian and Indonesian sample, respectively, and Mollah and Liljeblom (2016), who employ a multi-country sample. More papers are needed to analyse what the controversy observed for the U.S. is due to, and also more empirical papers should consider other institutional settings, especially emerging economies. For instance, Ali et al. (2018), using a self-constructed corporate governance index for a sample of non-financial firms in Australia, find that the negative effect on default risk is not significant for low-growth companies. The paper argues that high growth firms usually have higher shareholder-manager agency costs, and corporate governance mechanisms will have a greater impact on their credit risk. If we extrapolate this argument to a multinational context, we would expect that for less developed and emerging countries (with greater growth opportunities) the effect on default risk would be stronger.

\section{Other factors that moderate the relationship between internal corporate governance and credit risk}

In this section we present two factors that we believe could play an important role in the relationship between internal corporate governance and credit risk: the type of firm and the financial crisis. However, we must note that very few papers analyse differences based on these two factors. Thus, it is really difficult to draw conclusions regarding how these factors affect the impact on credit risk of the different corporate governance mechanisms summarized in this review. The few conclusions we have reached have been included in the summary in Table 6. Therefore, we call for further papers that extend this line of research.

\subsection{Type of firm: financial vs. non-financial}

We can see in Panel A of Table 7 the empirical papers grouped by the type of company they consider in their analysis. 53 \% (36/ 68 ) of the papers study non-financial firms, $43 \%$ (29/68) financial firms, and 4\% (3/68) both type of companies. We observe in Panel B of Table 7 that for financial firms, the mechanisms that are significantly more studied, in comparison to their non-financial counterparts, are: financial and non-financial ownership (5/0), foreign directors (5/0), foreign ownership (8/1) and state ownership (13/3). However, director tenure and managerial ability (0/4), the GIM and Bebchuk indices (0/4), institutional ownership (6/18), director networks and political connections (1/3), or insider ownership (5/9), are hardly or not at all analysed for the financial samples, and are, therefore, significantly predominant in samples composed of non-financial firms. Given the multiple factors that could explain the differences among the papers (such as the institutional setting or the way of measuring corporate governance variables), we would recommend more articles that explicitly analyse whether there are differences in the impact of internal corporate governance on credit risk between financial and non-financial firms.

Among the three papers that consider both types of companies in their analysis, only Switzer et al. (2018b) explicitly study the differences in the effect of corporate governance on credit risk between Canadian financial and non-financial firms. ${ }^{14}$ The paper reaches several conclusions. First, some variables are significant for the financial sample but not for non-financial firms. For instance, while insider ownership has an inverted U-shaped relationship with credit risk in financial firms, there is no effect for non-financial firms. Also, they find that board size and CEO duality increase credit risk for financial firms, but there is no significant effect for nonfinancial companies. However, these results contradict the findings of the papers that focus only on one type of firm (financial or nonfinancial). There is no consensus on the effect of insider ownership on credit risk for the financial sample and only two papers, out of the nine for non-financial samples, find a non-significant effect. In the case of board size, only one (two) papers among the nine (ten) that analyse financial (non-financial) companies find a positive (non-significant) effect. The same occurs with CEO duality. It is not clear whether it reduces or does not have an impact on credit risk for financial companies, while only one paper among those that analyse non-financial samples finds a non-significant effect.

Second, Switzer et al. (2018b) conclude that board independence increases (reduces) credit risk in financial (non-financial) firms, whereas institutional investors reduce (increase) credit risk in financial (non-financial) companies. These results are explained by the differences in regulation between both types of firms that affect the nature of monitoring, and is in line with the paper by Mehran et al. (2011) who highlight two main differences in the governance between U.S. financial and non-financial firms. One difference is related to the number of stakeholders, which is greater in financial firms. Another difference is related to the higher opacity and complexity of financial companies. However, although the number of articles is low, these results contradict the majority of papers focused on one or another type of company. In the case of board independence, most papers find, for financial firms, a negative or

\footnotetext{
${ }^{14}$ Note that the other two papers (Borisova et al., 2015; Mili and Abid, 2016) that consider in their analyses both types of companies, perform the analysis jointly and do not differentiate between them.
} 
Table 7

Empirical papers on the relationship between corporate governance and credit risk by firm type. Panel A shows the number of papers (among the sample of the 68 papers that we summarize in this systematic review) grouped by the type of company they consider in their analysis, distinguishing between non-financial, financial or both. Panel B displays, for each type of firm, the effect on credit risk of each internal mechanism, as well as the total number of papers, showing only the information from those articles that focus only on financial or non-financial companies.,+- and NS indicates an increase, decrease, and non-significant effect on the firm's credit risk, respectively. The different internal corporate governance mechanisms are distributed in three panels depending on ownership structure (Panel B.1), board composition (Panel B.2) and corporate governance indices (Panel B.3). The papers are identified by numerical codes, from 1 to 68, indicated in Appendix A.

\begin{tabular}{ll}
\hline \multicolumn{2}{l}{ Panel A: Number of papers by firm type } \\
\hline Type of firm & Papers \\
\hline Non-Financial & $\begin{array}{l}2,3,6,10,12,14,16,17,18,19,20,22,24,25,27,29,30,31,33,34,35,39,40,41,42,43,44,47,53,54,56,59,61, \\
62,63,65\end{array}$ \\
$\begin{array}{ll}\text { Financial } \\
\text { Both }\end{array}$ & $\begin{array}{l}1,4,5,7,8,9,11,13,21,23,26,28,32,36,37,38,45,46,49,50,51,52,55,58,60,64,66,67,68 \\
2\end{array}$ \\
\hline
\end{tabular}

Panel B: Corporate governance mechanisms and credit risk: financial versus non-financial firms

\begin{tabular}{|c|c|c|c|c|c|}
\hline \multicolumn{6}{|c|}{ Panel B.1: Ownership Structure } \\
\hline Corporate governance mechanisms & Effect & Financial papers & № Financial & Non-Financial papers & № Non-Financial \\
\hline \multirow[t]{3}{*}{ Institutional ownership } & + & 1,8 & 6 & $12,14,18,20,30,31,33,56,61$ & 18 \\
\hline & NS & $51,52,55$ & & $18,30,41,47,62,65$ & \\
\hline & - & 45,55 & & $\begin{array}{l}6,12,14,24,25,34,41,47,56 \\
63,65\end{array}$ & \\
\hline \multirow[t]{3}{*}{ State ownership } & + & $\begin{array}{l}13,21,23,26,28,37,58, \\
68\end{array}$ & 13 & & 3 \\
\hline & NS & $21,23,52$ & & 25,65 & \\
\hline & - & $38,45,51,67$ & & 43,65 & \\
\hline \multirow[t]{3}{*}{ Insider ownership } & + & $8,11,55,66$ & 5 & $18,25,47,59,61$ & 9 \\
\hline & NS & $11,55,64$ & & 35,47 & \\
\hline & - & 11,55 & & $6,25,33,35,61,65$ & \\
\hline \multirow[t]{3}{*}{ Ownership concentration } & + & $7,21,32,36,67$ & 7 & $6,16,25$ & 6 \\
\hline & NS & 21,37 & & & \\
\hline & - & 58 & & $43,53,62$ & \\
\hline \multirow[t]{3}{*}{ Foreign ownership } & + & $36,37,64$ & 8 & & 1 \\
\hline & NS & $23,26,37$ & & & \\
\hline & - & $23,28,58,68$ & & 42 & \\
\hline \multirow[t]{3}{*}{ Family ownership } & + & & 3 & 62 & 2 \\
\hline & NS & 51,52 & & 65 & \\
\hline & - & 8 & & 65 & \\
\hline \multirow[t]{3}{*}{ Excess control rights } & + & 51,52 & 2 & & 1 \\
\hline & NS & & & & \\
\hline & - & 51 & & & \\
\hline \multirow[t]{3}{*}{ Financial (bank) ownership } & + & 45 & 5 & & 0 \\
\hline & NS & $45,51,52$ & & & \\
\hline & - & 8,21 & & & \\
\hline \multirow[t]{3}{*}{ Non-financial (industry) ownership } & + & 45 & 5 & & 0 \\
\hline & NS & $8,45,51,52$ & & & \\
\hline & - & 21 & & & \\
\hline \multicolumn{6}{|c|}{ Panel B.2: Board Composition } \\
\hline \multirow[t]{3}{*}{ Board independence } & + & 21,46 & 10 & $53,59,61$ & 12 \\
\hline & NS & $5,49,55,64$ & & $18,29,33,59,65$ & \\
\hline & - & $4,5,13,36,49,55,66$ & & $6,10,12,19,31$ & \\
\hline \multirow[t]{3}{*}{ Board size } & + & 55 & 9 & 25,65 & 10 \\
\hline & NS & $1,5,21,36,49,55,64$ & & 18,33 & \\
\hline & - & $4,21,46,55$ & & $10,29,31,53,59,61$ & \\
\hline \multirow[t]{3}{*}{ CEO duality } & + & $36,46,55$ & 5 & $6,53,54,65$ & 6 \\
\hline & NS & $4,21,55$ & & 25 & \\
\hline & - & & & 29 & \\
\hline \multirow[t]{3}{*}{ Foreign directors } & + & & 5 & & 0 \\
\hline & NS & 5,23 & & & \\
\hline & - & $5,9,23,36,58$ & & & \\
\hline \multirow[t]{3}{*}{ Female directors } & + & & 2 & & 2 \\
\hline & NS & & & 31 & \\
\hline & - & 36,46 & & 18 & \\
\hline
\end{tabular}


Table 7 (continued)

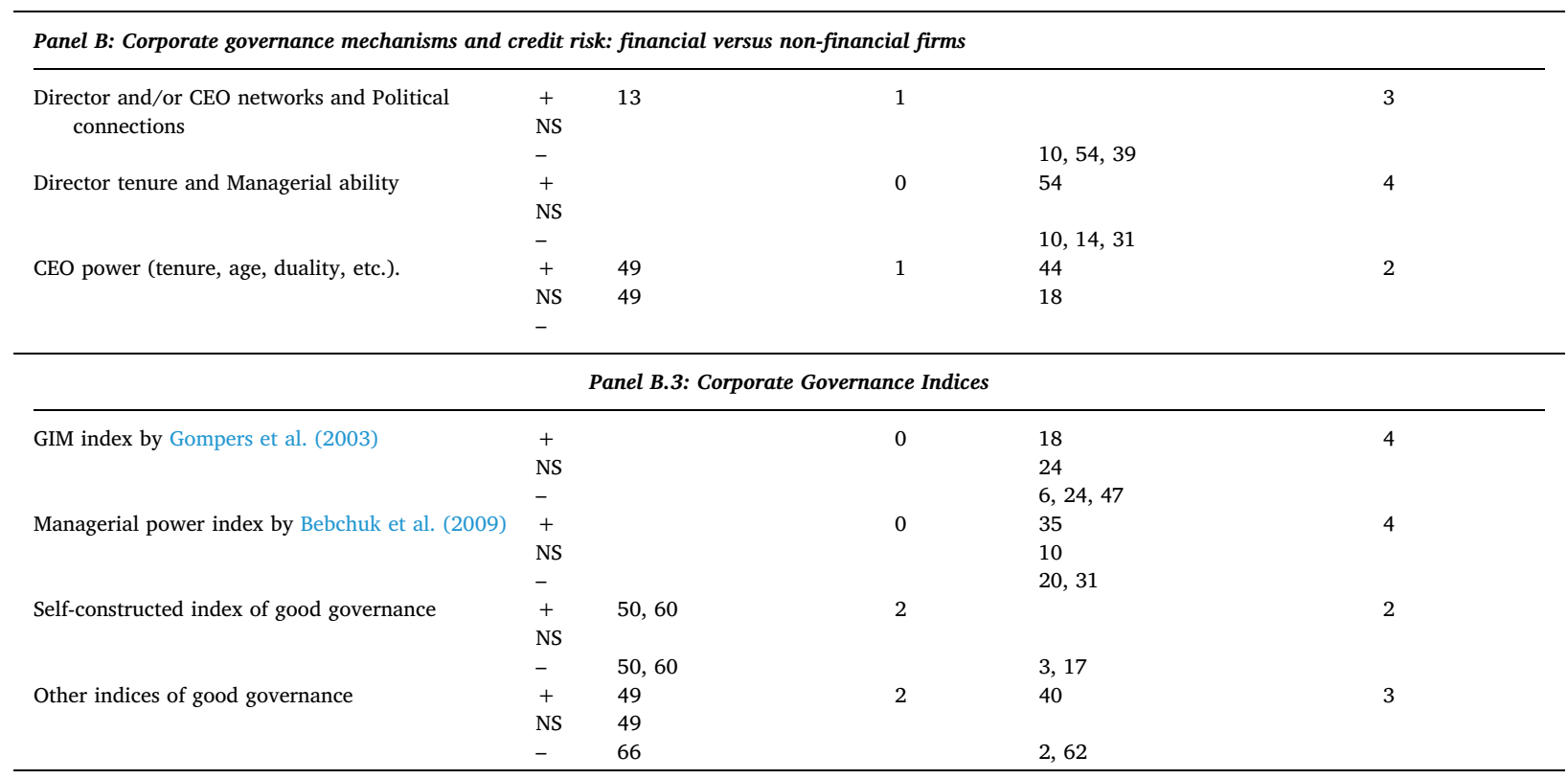

non-significant effect on credit risk, while in the case of non-financial samples the results are mixed. The results regarding institutional ownership are not in line with those of Switzer et al. (2018b) either. Most of the papers observe for the financial sample a positive or non-significant effect on credit risk and reach no consensus for non-financial firms.

On the other hand, from Panel B of Table 7 we can also obtain for both types of companies some additional conclusions for those mechanisms studied by a minimum number of papers, which allows us to reach some preliminary inferences. First, ownership concentration has a positive or non-significant effect on credit risk in most papers that analyse financial samples (the results are more mixed for samples composed of non-financial firms). Second, in non-financial firms, state ownership always has a negative or nonsignificant effect on credit risk, although the number of papers (four) is not enough to obtain a clear conclusion. Finally, the effect of board size on credit risk is in most cases non-significant or positive in financial firms, while results are more mixed for their nonfinancial counterparts.

Given the lack of papers that analyse differences between financial and non-financial firms in the role of internal governance in credit risk, we call for more research in this area that explains how differences in governance affect the level of credit risk of both groups of companies differently.

\subsection{Effect of the financial crisis}

In line with Mehran et al. (2011) or Mollah and Liljeblom (2016), among others, in this section we aim to analyse to what extent corporate governance has been re-structured in the aftermath of the 2008 global financial crisis. However, although there are many papers (46/68) that include the 2008 crisis in their sample period, very few (7) study the differences in the effect of corporate governance on credit risk distinguishing between the crisis and non-crisis period. On the other hand, although there are $22 / 68$ papers that focus on the non-crisis period, there are none that exclusively analyse the financial crisis period. In addition, the findings are contradictory for most mechanisms. All this makes it quite difficult to draw conclusions regarding the role that the crisis has played in the effect of the different corporate governance mechanisms on credit risk. ${ }^{15}$ Therefore, in this section we simply summarize the main results found in this area.

There are seven papers that include the role that the 2008 financial crisis played in the relationship between ownership structure and credit risk. First, regarding institutional ownership, Switzer and Wang (2017) show, for the case of the U.S., a positive effect of long-term institutional investors on credit risk, but the opposite effect during the global financial crisis period. This result suggests that this type of owner lowers its risk by shifting incentives during the crisis, since it is more concerned with the firm's survival. Additionally, the negative effect of short-term institutional owners on credit risk under normal conditions turned positive or nonsignificant during the financial crisis, which is consistent with the price pressure hypothesis, when selling behaviour during economic downturns aggravates the downward pressure on stock prices, increasing credit risk.

Second, in relation to state ownership, although Borisova et al. (2015) find, for a multi-country sample, that state ownership

\footnotetext{
${ }^{15}$ To preserve space, we do not include a table with the effect found for each mechanism depending on the sample period, but the authors will provide them if requested.
} 
increases a firm's credit risk, the effect was the opposite during the financial crisis. As they explain, this is because when the probability of default increases, debtholders value the implicit government guarantees more highly, while these state interventions are not valued under normal economic circumstances. Also, Cornett et al. (2010) show, for a sample of Asiatic banks, that the positive impact of state shareholdings on credit risk disappeared during the post Asian crisis period. They attribute this result to the improvement of the state-owned banks in the post-crisis period, and it is in line with Zhu and Yang (2016), who also find that the positive effect of state ownership in China was lower during the global financial crisis.

Finally, Yen et al. (2015) conclude that in Taiwan the negative effect of founder ownership on credit risk was higher during the 2008 crisis, in line with the resilience of family firms during the financial crisis as demonstrated by Crespi and Martin-Oliver (2015), who find these firms to be less subject than non-family firms to credit restrictions during economic downturns. Also, Saghi-Zedek and Tarazi (2015) detect that during the 2008 financial crisis, the increasing effect of excess control rights on credit risk disappeared, but only in firms controlled by a family or in those European countries with low shareholder protection. However, this result is in contrast to that of Lin et al. (2011), who, using a sample of East Asian and European countries, show that the divergence between cash flow and voting rights has a deeper positive impact on credit risk for companies in countries experiencing a financial crisis.

With respect to the board composition, there are four papers that analyse the role played by the crisis. First, Andries and Brown (2017) find that in 17 emerging countries in central and Eastern Europe, a higher proportion of foreign board members is associated with lower credit risk only during the crisis period. This result may be reflecting higher levels of risk aversion in the case of these strategic investors than in the case of national investors. Second, Ferreira and Matos (2012) analyse in a multi-country study the role played by the representation on boards or the holding of shares by the creditors in non-financial firms. While they find a positive relationship between the presence of creditors on the board and the firm's credit risk, the effect is negative during the financial crisis. In other words, under favourable economic conditions creditors take advantage of their insider position to pressure firms to take on loans at higher interest rates, but during financial crises they charge lower spreads. Third, Mollah and Liljeblom (2016) highlight, also in a multi-country sample, interesting differences explained by the global financial crisis of 2008 and the European sovereign debt crisis. Only during the latter crisis did CEO power have an impact on credit risk. However, while credit risk measured as 1 divided by the z-score is increased, credit risk is reduced when measured by the ratio of non-performing loans. After the 2008 financial crisis, the quality of corporate governance received much more attention, which led, among other things, to lower levels of non-performing loans during the subsequent sovereign debt crisis. In fact, during this latter crisis, more powerful CEOs obtained better levels of performance (measured by ROA), despite showing a higher insolvency risk (in terms of Z-score). Finally, Ames et al. (2018) show that the existence of a board risk committee lowers the credit risk of U.S. insurance companies, but only in the post-financial crisis period. As a consequence of the 2008 crisis, the financial and insurance companies underwent greater scrutiny, and the external evaluators became more concerned with the presence of a risk committee of the board of directors as an effective mechanism for board risk governance.

Overall, given the lack of empirical papers that analyse the moderating role played by the crisis on the relationship between internal corporate governance and credit risk, we call for more studies that allow us to understand how the crisis period influenced the effectiveness of each mechanism on credit risk.

\section{Measurement of credit risk}

There is a wide variety of measures that have been used as a proxy for credit risk, interchangeably by academics and practitioners. Some, such as Altman's (1968) Z-score or Ohlson's (1980) O-score, are based on accounting data. Others, such as BSM, bond spreads or credit default swap (CDS) spreads, are based on market information. Widely used is also the credit solvency assessment collected in the credit ratings and carried out by rating agencies. Another alternatives would be non-performing loans or bond recovery rates, among others.

In this section we provide a brief review of the alternative measures of credit risk used in the papers included in this systematic review. It is important to consider that the differences in results may also be due to the different methods used to approximate credit risk. ${ }^{16}$ Table 8 shows the number of papers using each credit risk measure.

Most of the literature that explores the influence of corporate governance mechanisms on credit risk uses issuer credit ratings as a proxy for the default probabilities for the companies. As we observe in Table 8, this measure is used by $35 \%$ (24/68) of the papers included in this systematic review.

The credit ratings used were based on the long-term issuer credit ratings compiled by the three major credit rating agencies (Standard and Poor's (S\&P), Fitch, and Moody's Investing Service). These ratings reflect an assessment of firm credit worthiness with respect to its senior unsecured debt obligations. In this regard, S\&P's bond credit rating data is the primary public source of this data used extensively in the finance literature. ${ }^{17}$ For S\&P, the bond ratings range from AAA (highest grade) to D (in default). The

\footnotetext{
${ }^{16}$ In fact, studies such as Gharghori et al. (2006) and Hillegeist et al. (2004) show that market-based models given by BSM or similar are superior to its accounting counterparts when it comes to predicting default risk. More recently, after examining the predictive power of eight default risk indicators Abínzano et al. (2020) conclude that market-based models, and specially CDSs, clearly outperform accounting measures and credit rating.

${ }^{17}$ After making a comparison of the ratings from the three major agencies, Beaver et al. (2006) conclude that these ratings are fairly similar and consistent, suggesting that relying on one bond rating agency is sufficient. In fact, most papers use only S\&P credit ratings, except Bhojraj and Sengupta (2003), which uses Moody's ratings, Li and Wang (2016) and Liu and Jiraporn (2010), which combine S\&P and Moody's ratings, and Ames et al. (2018), which uses A.M. Best's Financial Strength Ratings, a measure widely used in the insurance industry to assess financial health.
} 


\section{Table 8}

Credit risk measures. This table shows the number of papers (from among the sample of the 68 papers that we summarize in this systematic review) by credit risk measure used. The papers are identified by numerical codes, from 1 to 68, following the list indicated in Appendix A.

\begin{tabular}{ll}
\hline Credit risk measure & Papers \\
\hline Credit rating & $2,4,6,10,12,14,17,19,22,24,29,35,36,38,40,41,44,45,47,53,54,59,61,62$ \\
Non-performing loan (NPL) ratios & $1,5,9,11,13,21,23,26,37,45,46,49,50,58,60,66,67,68$ \\
Bond credit spread & $12,14,15,17,20,27,33,35,40,41,44,47,59,63,65$ \\
Distance to default (DD) & $3,7,16,18,25,49,52,55,57,64$ \\
Z-score & $8,11,23,28,37,49,51,52,67$ \\
Bank loans and loans spreads & $30,31,34,39,43,54,61,65$ \\
Credit default swap spreads & $3,32,55,56$ \\
Bond recovery rates & 48 \\
\hline
\end{tabular}

methodology used is to translate credit ratings into numbers, with a larger number indicating a better rating. The vast majority of papers that use credit ratings are focused on U.S. firms. Of the twenty-four papers that use credit ratings, only seven of them use a sample not composed of U.S. firms. They consider European and Islamic banks or data from Korea, Malaysia, Indonesia, Japan and Taiwanese firms. ${ }^{18}$ With regard to the sample periods, approximately $60 \%$ of the studies analyse the period that includes the global financial crisis of 2008.

The second most widely used measure to approximate credit risk is the non-performing loan (NPL) ratio. This ratio measures the percentage of loans held by a bank that are likely to default, and it is frequently used to estimate bank failure. A higher NPL ratio indicates greater credit risk (ElBannan, 2015; Gonzalez, 2005). ${ }^{19}$ The group of papers that apply this measure are studies focused on financial institutions. ${ }^{20}$ As can be seen in Table 8, the percentage of papers that work with this measure amounts to $27 \%$ of the papers $(18 / 68)$, among which we find a great variety of different samples. While two (one) papers use pre- (post-) crisis data samples, the rest of the papers include the period covered by the 2008 crisis. Four papers focus exclusively on U.S. commercial banks, three focus on banks in China, while three others analyse the financial sector of European countries, one of which includes the period of the sovereign debt crisis in the Eurozone. The rest of the works cover other countries and carry out studies on emerging countries (including China), Tunisia, India, Philippines, Bangladesh and the U.K. Finally, two papers use broad samples with international global banks.

The third most used measure is the bond credit spread. As noted by Liu and Jiraporn (2010) or Mansi et al. (2009), this measure has been widely employed in the literature to capture the ex-ante cost of debt. As Table 8 shows, $22 \%$ (15/68) of the papers included in this review use it. The bond spread is expressed in basis points and is computed as the difference between the yield of the corporate bond and the yield of a benchmark government bond that is matched by currency and maturity. The greater the bond credit spread of a company, the higher its credit risk. Most of the papers that use this measure (10/15) examine non-financial firms in the U.S. Of these, only two analyse the existing relationship for the period that includes the global financial crisis of 2008. The rest of the works include samples from other countries, such as Borisova et al. (2015), which carries out an international study on 43 countries (including the U.S., the U.K., Europe, Asia, etc.) with a large number of both financial and non-financial companies, while others focus on Korea, China, Japan or Taiwan.

Some more recent works utilise CDSs as an alternative measure to the bond credit spread. Currently, CDSs are the most popular credit derivative with the simplest structure in this market. It is a contract that provides protection against the risk of failure or insolvency of a given company. ${ }^{21}$ CDSs are considered a good proxy for the riskiness and default probability of countries/firms expressed in basis points. They reflect market perceptions about the financial health of countries/firms, providing a signal with respect to financial stability. However, only four of the papers included in this review use this measure of credit risk (Table 8), which we identify as a clear line of future research given the extensive use being made of these derivative assets for other types of empirical works in finance. Two of the four papers carry out studies on non-financial firms in Austria and the U.S., respectively, while the other two undertake analyses with intra-national samples, analysing banks from 23 countries (U.S., Australia, Western Europe and Asia) or looking at 117 banks from 28 countries (Australia, Western Europe, Asia and South America). All these papers include recent data that encompasses the global financial crisis of 2008.

Other works (10/68) utilise what is known as distance to default (the DD measure) as a proxy for the default risk. This is a

\footnotetext{
${ }^{18}$ It should be noted that Shu et al. (2015) use as a credit rating measure the Taiwan Corporate Credit Risk Index (TCRI) score as the proxy for firm credit risk.

${ }^{19}$ Note that Andries and Brown (2017) use the ratio of the end-stock of non-performing loans (NPL) to gross loans as well as the ratio of annual loan loss provisions (LLP) to gross loans as measures of credit losses. In addition, as a measure that approximates the credit growth, the paper uses the year-on-year growth of gross loans.

${ }^{20}$ Given the peculiar nature of the banking business, credit risk has been identified as one of the most important risks to which financial institutions are subject (Maltritz and Molchanov, 2014).

${ }^{21}$ This company is known as the reference entity and its failure is known as a credit event. In this way, the buyer of the protection can transfer the risk of non-payment, so the CDS is a product that provides insurance against the risk of default by a given issuer (company or country). In exchange for such protection, the buyer of the CDS (protection buyer) makes periodic payments to the seller (protection seller) until the end of the contract or until the credit event occurs.
} 
measure that uses the option pricing approach developed by Black and Scholes (1973) and Merton (1974) and provides an appealing alternative to the prediction of default risk conditions of listed firms. ${ }^{22}$ The advantage of using these models to estimate credit risk is that they include a 'refined' volatility assessment that aids in predicting the risk of default. Following this model, the greater the positive distance between firm value and firm liabilities, the lower the probability of default risk. Table 8 shows how $12 \%$ of the papers (9/68) use this measure. The works that use the DD measure analyse both financial and non-financial firms. Regarding financial institutions, two papers consider international global banks for a time period that includes the 2008 global financial crisis, another uses Western European countries (including the U.K.) also including the crisis period, and two other papers focus on European and Japanese financial institutions for the period prior to the crisis. In the case of non-financial firms, the samples include firms from Australia, Taiwan or the U.S. (although one of the papers only includes data up to 2005). The only paper that shows the comparison between financial and non-financial companies is the one by Switzer et al. (2018b), which utilises data from Canadian firms.

A similar percentage to the previous group of papers (9/68) use the Z-score measure as a proxy for credit risk. This measure is another insolvency risk variable used as an indicator of financial stability (e.g. Laeven and Levine, 2009). It is is calculated as the return on assets plus the capital-asset ratio divided by the standard deviation of asset returns. A higher Z-Score indicates that a bank is more stable, as it is inversely related to the bank's probability of insolvency. All the papers that use this measure as a proxy focus on financial institutions, encompassing different countries in their analyses. Mollah and Liljeblom (2016) is the paper with the largest data sample with global banks from Japan, China, France, India, Italy, Spain, the U.K. and the U.S. Of the rest of the paper three focus on banks from Western European countries, while others consider U.S. banks, Egyptian banks, Indian banks, Chinese banks or banks from Bangladesh. All of them except two analyse a recent sample period including the global financial crisis of 2008.

Another method used to analyse the effect of corporate governance on default risk is through loan spreads. This spread is a proxy for the interest cost of debt and is measured as the drawn all-in spread (plus the upfront fee and annual fee, if any) in basis points in excess of the benchmark rate (i.e., the LIBOR). Following this line, Ferreira and Matos (2012) is the reference paper that includes a broad international sample, including companies from the U.K., the U.S., Europe, Latin America, Asia and Australia. Other authors focus on companies from East Asia and Western Europe, or use data from U.S. and Taiwanese companies. It should be noted that all of them include the global financial crisis in their sample period. In the same vein, some of the papers use various characteristics of bank loans to study the topic in non-financial firms.

Lastly, Mili and Abid (2016) examine the relationship between corporate governance and the recovery rates of corporate bonds. This study encompassing financial and non-financial U.S. firms is the only one that uses this measure of credit risk. These rates are an important component of credit risk. Generally, the bond recovery rate is computed as the value of the bond just after the default and is expressed in terms of its face value. It is equal to one minus the loss given default.

\section{Methodology}

In this section we focus on the endogeneity problem inherent in most empirical papers in corporate governance and corporate finance. We provide a short review of the sources of endogeneity with an example and highlight the need to address it. Finally, we briefly present the econometric techniques that can be used to address this problem and show the number of papers that, in one way or another, deal with it.

Wooldridge (2010) defines endogenous variables as those that are correlated with the error term. This is one of the assumptions of OLS, which produces inconsistent estimates if the assumption is violated. There are three possible sources of endogeneity: omitted variables, measurement error and reverse causality. The first source appears when the model does not include all the variables that explain the dependent one, due to data unavailability or unobservable variables. The second source, measurement error, occurs when the explanatory or dependent variables are measured using proxies, leading to a discrepancy between the true variable and the proxy. The third source of endogeneity, reverse causality, arises when at least one of the explanatory variables is determined simultaneously along with the dependent variable. Regardless of the source type, endogeneity will occur whenever the source leads to correlation between the error term and any of the explanatory variables.

As pointed out by Roberts and Whited (2013), before addressing endogeneity it is crucial to discuss its causes and consequences. We provide an example where the three sources lead to an endogeneity problem. Imagine a model where family ownership aims to explain the firm's credit rating, which is the dependent variable. The omitted variable problem occurs if we do not consider the attachment of family members to the business, which is a not-observable variable. We should include this variable in the model because the level of commitment that family members acquire towards the company will have an impact on the firm's credit risk. Furthermore, family attachment is also correlated with the explanatory variable, the shares held by the family, since more attached family members will participate more in the firm's shares. The second source of endogeneity, measurement error, is also present in this model, for both the dependent and independent variables, since credit rating and family ownership are proxies used to measure the firm's credit risk and family control, respectively. There is endogeneity because the measurement error is correlated with some of the explanatory variables. In this example, as in most models, the measurement error of the dependent variable is correlated with other explanatory variables, such as size, since the "too big to fail" effect will cause larger companies to have higher credit ratings

\footnotetext{
${ }^{22}$ The model views the firm's equity value as a European call option on the firm's assets, with a strike price equal to the face value of the firm's liabilities. When the value of the equity is positive (zero), if the firm's value exceeds (falls below) the level of liabilities at the time of maturity, shareholders exercise (do not exercise) their option and the company survives (defaults).
} 


\section{Table 9}

Empirical papers on the relationship between corporate governance and credit risk by methodology employed. This table shows the number of papers (among the sample of the 68 papers that we summarize in this systematic review) grouped by the type of methodology they consider in their analysis, focusing on the endogeneity problem. The papers are identified by numerical codes, from 1 to 68 , following the list indicated in Appendix A.

\begin{tabular}{|c|c|c|c|}
\hline \multicolumn{2}{|l|}{ Econometric technique } & Papers & No. of papers \\
\hline \multicolumn{2}{|c|}{ No technique that address endogeneity } & $5,6,7,9,18,28,35,42,53,62,64$ & 11 \\
\hline \multicolumn{2}{|c|}{ Instrumental variables } & $3,10,15,20,24,26,30,31,34.40,43,44,45,47,52,54,55,56,58,59,61,66,67$ & 23 \\
\hline \multicolumn{2}{|c|}{ Difference-in-differences estimators } & $16,19,23,33,49,68$ & 6 \\
\hline \multirow[t]{3}{*}{ Panel data methods } & Fixed effect & $1,3,14,15,16,19,20,22,24,27,30,33,38,39,40,43,44,46,54,56,61,65$ & 22 \\
\hline & Random effect & $32,45,46,67$ & 4 \\
\hline & $\mathrm{Gmm}$ & $3,13,25,37,46,48,50,51,52,58,60,66$ & 12 \\
\hline \multicolumn{2}{|c|}{ Matching methods } & $4,15,16,19,22,23,30,33,57,68$ & 10 \\
\hline \multicolumn{2}{|c|}{ Heckman two-stage approach } & $4,8,11,15,41,47,56,59$ & 8 \\
\hline \multicolumn{2}{|c|}{ Simultaneous equation approach } & $2,12,17,20,21,29,36,49,61,63,65$ & 11 \\
\hline
\end{tabular}

that do not necessarily reflect the true level of credit risk, and therefore the measurement error will be correlated with size. In addition, the measurement error of the explanatory variable, family ownership, may be greater in less leveraged companies since they will rely more on equity issuance to obtain financing, which would reduce the shares held by the family. Under this scenario, family ownership will be lower, but that will not necessarily be the case for the family control that is represented not just by the family shares. Therefore, the measurement error of family ownership is correlated with the leverage of the firm. Finally, we find in this example an endogeneity problem caused by reverse causality, the third source of endogeneity, since not just family ownership explains credit risk, but the level of credit risk can be a factor that families consider when deciding the type of company to invest in. As a result, the error term is correlated with the explanatory variables.

Once the endogeneity problem is properly discussed, researchers should consider other techniques, different from OLS, that address this problem. Roberts and Whited (2013) provide a good summary with the main advantages and drawbacks of econometric techniques aimed at addressing endogeneity. The most common techniques are: instrumental variables, difference-in-differences estimators, panel data methods, and matching methods. There are others, such as the Heckman two-stage approach, which can also be used to address selection bias, which causes an endogeneity issue and arises from observable and unobservable differences between two groups of companies; or simultaneous equation approaches that address reverse causality.

We find in Table 9 that the use of instrumental variables is the predominant technique, used by $34 \%$ of papers (23/68). In addition, many papers employ panel data methods such as fixed effect, generalized method of moments, or random effect, used by 32 $\%(22 / 68), 18 \%(12 / 68)$ and $6 \%(4 / 68)$ of articles, respectively. Other techniques aimed at addressing selection bias, such as matching methods, Heckman two-stage approach or difference-in-differences are used by $15 \%$ (10/68), 12\% (8/68), and 9\% (6/68) of the papers in this systematic review. In addition, $16 \%(11 / 68)$ of the papers use no techniques that address endogeneity, or use simultaneous equations that do not include instrumental variables.

\section{Conclusions}

As noted in the two recent systematic reviews by John et al. (2016) and Schiehll and Martins (2016), the relationship between corporate governance and firm value has been widely studied in the literature. We differentiate from them by providing, for the first time, a review of internal corporate governance mechanism implications on firm default risk, rather than performance. There is a widespread view that weak corporate governance practices lead to a higher probability of default, and consequently contribute to instability in international financial markets. In this context, we discuss the existing evidence on this topic in order to determine what we have learnt about the relationship between corporate governance and credit risk.

Our main focus is the analysis of the institutional setting as a factor that moderates the relationship between internal corporate governance and credit risk. We intend to assess to what extent agency theory, developed for the Anglo-Saxon model (in particular, for the U.S. context, which is the institutional setting most studied), and its consequences with regard to corporate governance mechanisms, can be extrapolated to other settings. We obtain several conclusions. On the one hand, inferences based on the firm's country could not be obtained for institutional, insider or financial and non-financial ownership, since there are other factors, such as the heterogeneity of these types of investors, that should be considered first. The same occurs with board independence, whose mixed results found in all settings may be explained by non-linear effects. In addition, there are some mechanisms, such as board and CEO networks, political connections, director tenure, managerial ability or CEO power, that are studied by a limited number of papers, and, therefore, conclusions based on the institutional setting cannot be obtained. A similar problem occurs with the corporate governance indices, which are mainly analysed for U.S. companies.

On the other hand, we were able to find differences in the effect of some internal corporate governance mechanism on credit risk, 
explained by the institutional setting. First, state ownership increases credit risk in emerging countries characterized by the strong presence of the state in private companies. Second, only in settings with high ownership concentration, such as Asia and Europe, does the concentration of ownership reduce credit risk. Third, credit risk increases with higher foreign ownership in countries with cultural peculiarities that may hinder the adaptation of foreign investors (such as Japan, India or Islamic countries), but reduces it in countries, such as China, where foreign investors are seen as an alternative to state ownership. Fourth, although the number of papers is not large enough to offer a clear conclusion, it seems that the effect of family ownership on credit risk is negative only in European countries where the use of control chains, such as excess control rights, is lower. Fifth, there seems to be an agreement for all settings on the positive effect of CEO duality and the negative effect of female and foreign directors on credit risk. Finally, there is not a clear pattern on the effect of board size on credit risk in Asia and Europe, but it seems to decrease credit risk in the North American and U.K. context.

We also check whether the conclusions depend on the type of firms and the time-period considered in the analysis, since we believe these could play an important role in the relationship between internal corporate governance and credit risk. Regarding the firm type, there is only one paper that explicitly analyses differences between financial and non-financial firms, and its conclusions contradict the results found by those authors that focus exclusively on financial or non-financial samples. Regarding the role played by economic downturns, we find that during crisis periods some positive effects on credit risk turn negative (long-term institutional investors) or disappear (state ownership), and negative effects become lower (foreign directors) or higher (family ownership). However, we must note that the literature in this regard is quite scarce. More studies are needed to provide robust conclusions and a clear understanding of the differences of the effect of each mechanism on credit risk based on the firm type and time period.

In addition, we show the measures of credit risk which are most used by the papers in this review. The main proxies used in order to explore the impact of corporate governance mechanisms on default risk are the credit ratings, the non-performing loans ratio and the bond credit spreads. Much less used are the Z-score, the bank loans, the loan spreads, the CDS spreads and finally the bond recovery rates. Articles that use the credit rating as a measure of credit risk are quite rare and not very developed for European companies or those from emerging countries (either as individual countries or as a group). Moreover, the scant evidence that exists for Europe is only for financial institutions. There is also a scarcity of papers that analyse banks using the NPL measure for Europe and that also include the European sovereign debt crisis in their analysis. Papers that use the bond spread measure for the US and that take into account the global financial crisis are very limited, and results for emerging countries are practically non-existent. Given the growth of CDS spreads in recent years, it seems that these credit spreads are to some extent replacing bond spreads as a proxy for credit risk. It would also be very interesting if researchers could empirically analyse the relationship between internal corporate governance mechanisms and credit risk, using both accounting and market measures together. Finally, being aware that when comparing different findings, we should be cautious with the methodology employed in the analysis, we conduct a brief review in relation to this issue. As pointed out by Ashbaugh-Skaife et al. (2006), it is important to consider several corporate governance factors in order to avoid the problem of omitted variables, which is one of the sources of endogeneity (Wintoki et al., 2012). We find that 84 $\%$ of the papers use some methodology to overcome this issue, with instrumental variables and panel data estimators being the predominant techniques used.

Finally, the systematic review allows us to identify future lines of research that remain to be addressed. First, we call for more studies beyond the U.S. setting, as well as additional multinational samples that explicitly analyse differences between countries, firm types and time periods. In this regard, some countries should be of great interest given their specific regulations that affect some of the corporate governance mechanisms, such as foreign ownership or female directors, and, therefore, affect the firm's credit risk. Second, more papers are needed that analyse the heterogeneity of some types of investors or directors that may affect their behaviour and, in the end, could have a different effect on credit risk. Third, it would be useful to have papers that employ, as robustness, different definitions for their credit risk and corporate governance proxies, consider the possibility of non-linear effects for some mechanisms, and use the appropriate methodology to control the endogeneity of the models. Finally, more studies should be done with non-financial samples on the effect of state ownership, foreign ownership, and director, financial and non-financial ownership on credit risk. There is also a need for more studies with financial samples on the effect on credit risk of director networks and political connections, director tenure and managerial ability.

This systematic review may assist policy makers who pursue the implementation of the best corporate governance practices by firms in order to prevent future financial scandals, corporate bankruptcy and their non-desirable consequences for the economy. This review also has important implications for investors when deciding on their target companies to invest in.

\section{Funding}

The authors acknowledge financial support from the Fundación Ramón Areces. Laura Ballester acknowledge financial support from the Spanish Ministry of Science, Innovation and Universities and FEDER project PGC2018-093645-B-I00. In addition, Laura 
Ballester and Ana González-Urteaga acknowledge financial support from the Spanish Ministry of Science, Innovation and Universities through grant PGC2018-095072-B-I00, and Ana González-Urteaga and Beatriz Martínez acknowledge financial support from the Ministry of Economics and Competitiveness through grants ECO2016-77631-R (AEI/FEDER.UE) and PID2019-104304GB-I00 and UPNA Research Grant for Young Researchers, Edition 2018.

\section{Appendix A}

This appendix shows in alphabetical order the list of the 68 papers that we summarize in this systematic review, together with a numerical code in brackets, from 1 to 68 .

\begin{tabular}{|c|c|c|c|}
\hline Code & Paper & Code & Paper \\
\hline [1] & Akwaa-Sekyi and Gene (2017) & {$[35]$} & Ghouma (2017) \\
\hline$[2]$ & Alali et al. (2012) & {$[36]$} & Grassa (2016) \\
\hline [3] & Ali et al. (2018) & [37] & Haque and Shahid (2016) \\
\hline [4] & Ames et al. (2018) & {$[38]$} & Iannotta et al. (2013) \\
\hline [5] & Andries and Brown (2017) & [39] & Infante and Piazza (2014) \\
\hline [6] & Ashbaugh-Skaife et al. (2006) & {$[40]$} & Jiraporn et al. (2013) \\
\hline [7] & Auvray and Brossard (2012) & [41] & $\mathrm{Li}$ and Wang (2016) \\
\hline [8] & Barry et al. (2011) & [42] & Lim and Mali (2018) \\
\hline [9] & Ben Saada (2018) & [43] & Lin et al. (2011) \\
\hline [10] & Benson et al. (2018) & [44] & Liu and Jiraporn (2010) \\
\hline [11] & Berger et al. (2016) & {$[45]$} & Liu and Yeh (2018) \\
\hline [12] & Bhojraj and Sengupta (2003) & {$[46]$} & Lu and Boateng (2018) \\
\hline [13] & Boateng et al. (2019) & [47] & Mansi et al. (2009) \\
\hline [14] & Bonsall et al. (2017) & {$[48]$} & Mili and Abid (2016) \\
\hline [15] & Borisova et al. (2015) & [49] & Mollah and Liljeblom (2016) \\
\hline [16] & Brogaard et al. (2017) & {$[50]$} & Safiullah and Shamsuddin (2018) \\
\hline [17] & Byun (2007) & {$[51]$} & Saghi-Zedek (2016) \\
\hline [18] & Cao et al. (2015) & {$[52]$} & Saghi-Zedek and Tarazi (2015) \\
\hline [19] & Chen (2014) & [53] & Shu et al. (2015) \\
\hline [20] & Chen et al. (2017) & [54] & Skousen et al. (2018) \\
\hline$[21]$ & Chen and Lin (2016) & {$[55]$} & Switzer et al. (2018a) \\
\hline$[22]$ & Chen et al. (2016) & {$[56]$} & Switzer and Wang (2017) \\
\hline [23] & Cheng et al. (2016) & [57] & Switzer et al. (2018b) \\
\hline [24] & Cheng and Subramanyam (2008) & {$[58]$} & Tacneng (2015) \\
\hline [25] & Chiang et al. (2015) & [59] & Tanaka (2016) \\
\hline [26] & Cornett et al. (2010) & {$[60]$} & Tarchouna et al. (2017) \\
\hline [27] & Cremers et al. (2007) & [61] & Upadhyay (2015) \\
\hline [28] & ElBannan (2015) & {$[62]$} & Utama et al. (2016) \\
\hline [29] & Elhaj et al. (2018) & [63] & Wang and Zhang (2009) \\
\hline [30] & Ferreira and Matos (2012) & [64] & Yeh (2017) \\
\hline [31] & Fields et al. (2012) & {$[65]$} & Yen et al. (2015) \\
\hline$[32]$ & Froneberg et al. (2016) & {$[66]$} & Zagorchev and Gao (2015) \\
\hline [33] & Gao and Lin (2018) & {$[67]$} & Zheng et al. (2017) \\
\hline [34] & Ge et al. (2017) & {$[68]$} & Zhu and Yang (2016) \\
\hline
\end{tabular}

\section{Appendix B}

This appendix shows the effect of the different corporate governance mechanisms reviewed for each institutional setting, including single-country papers (coloured in grey) and multi-country papers, where Eu denotes Europe, NA denotes North America, SA denotes South America, As denotes Asia, Au denotes Australia, Af denotes Africa, EA denotes East Asia, GCC denotes Gulf Cooperation Council countries, and Sa denotes South Asia. The table presented below aims to provide a clear picture of the role that the institutional setting plays in the relationship between internal corporate governance and credit risk. More concretely, this table shows the effect on credit risk of each internal mechanism analysed in the literature (among the sample of the 68 papers that we summarize in this systematic review) for each institutional setting, where + , - and NS indicates an increase, decrease, and nonsignificant effect on the firm's credit risk, respectively. The different internal corporate governance mechanisms are distributed in three panels depending on ownership structure (Panel A), board composition (Panel B) and corporate governance indices (Panel C). The papers are identified by numerical codes, from 1 to 68, indicated in Appendix A. 


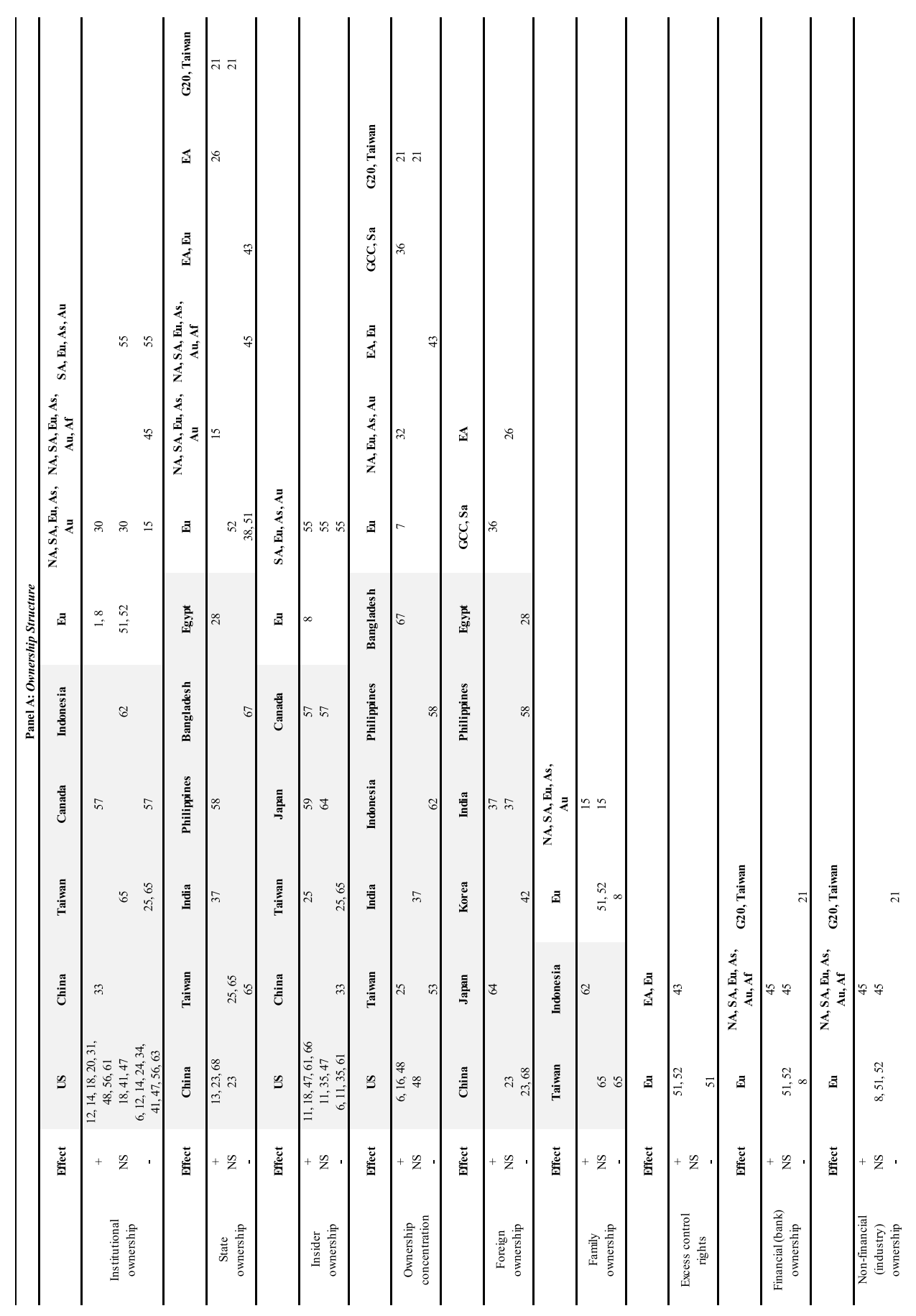




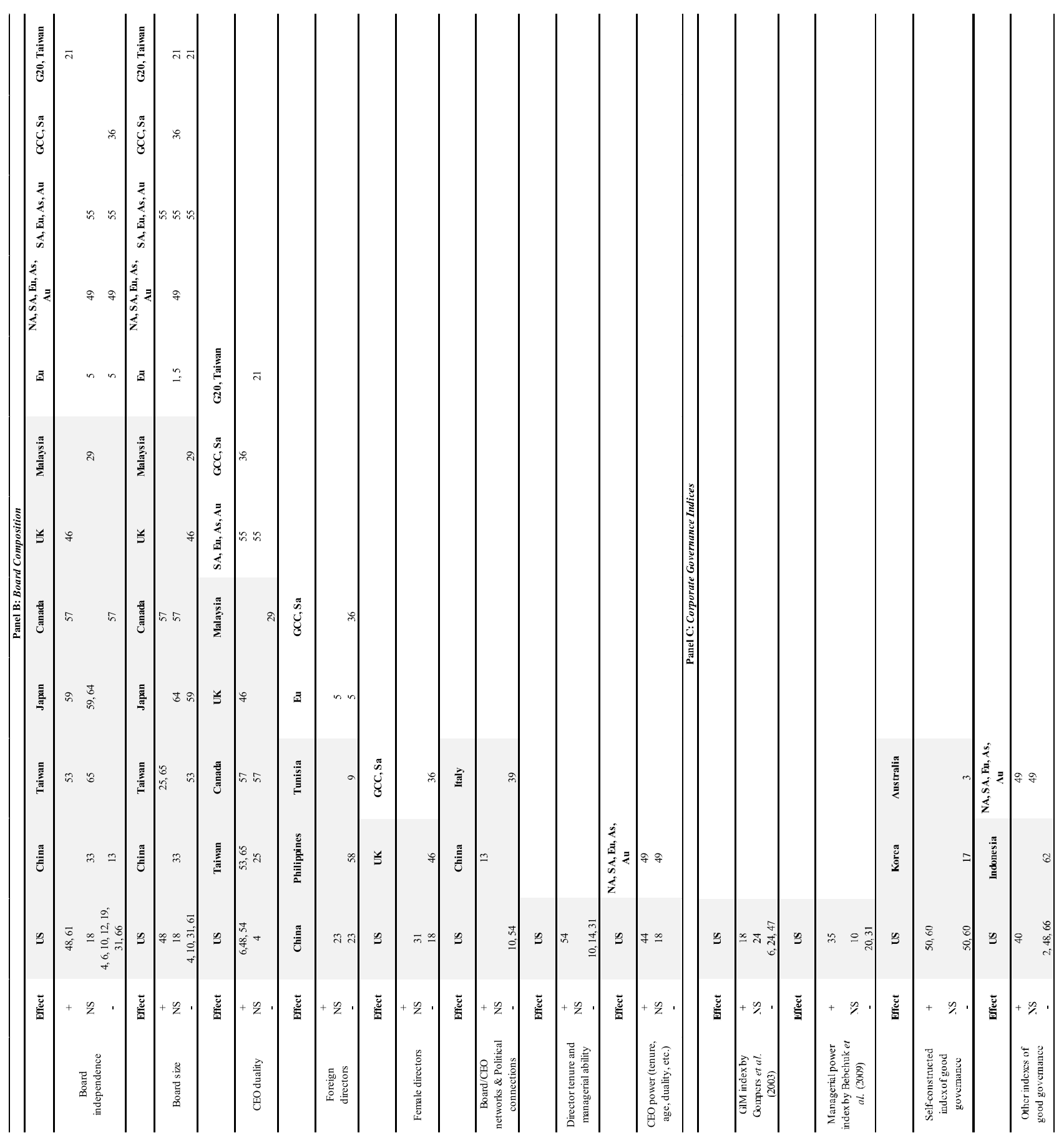




\section{References}

Abínzano, I., González-Urteaga, A., Muga, L., Sanchez, S., 2020. Performance of default-risk measures: sample matters. Working paper. Adams, R.B., Almeida, H., Ferreira, D., 2005. Powerful CEOs and their impact on corporate performance. Rev. Financ. Stud. 18, 1403-1432. Akwaa-Sekyi, E.K., Gene, J.M., 2017. Internal controls and credit risk relationship among banks in Europe. Intang. Cap. 13, 25-50.

Alali, F., Anandarajan, A., Jiang, W., 2012. The effect of corporate governance on firm's credit ratings: further evidence using governance score in the United States. Account. Financ. 52, 291-312.

Ali, S., Liu, B., Su, J.J., 2018. Does corporate governance quality affect default risk? The role of growth opportunities and stock liquidity. Int. Rev. Econ. Financ. 58, $422-448$.

Altman, E.I., 1968. Financial ratios, discriminant analysis and the prediction of corporate bankruptcy. J. Finance 23 (4), $589-609$.

Ames, D.A., Hines, C.S., Sankara, J., 2018. Board risk committees: insurer financial strength ratings and performance. J. Account. Public Policy 37, 130-145. Anderson, R., Reeb, D., 2003. Founding-family ownership and firm performance: evidence from the S\&P 500. J. Finance 58, $1301-1328$.

Andries, A.M., Brown, M., 2017. Credit booms and busts in emerging markets: the role of bank governance and risk management. Econ. Transit. $25,377-437$. Ashbaugh-Skaife, H., Collins, D.W., LaFond, R., 2006. The effects of corporate governance on firms' credit ratings. J. Account. Econ. 42 , 203-243.

Auvray, T., Brossard, O., 2012. Too dispersed to monitor? Ownership dispersion, monitoring, and the prediction of bank distress. J. Money Credit Bank. 44, 685-714. Barry, T.A., Lepetit, L., Tarazi, A., 2011. Ownership structure and risk in publicly held and privately owned banks. J. Bank. Financ. 35, 1327-1340.

Beaver, W.H., Shakespeare, C., Soliman, M.T., 2006. Differential properties in the ratings of certified versus non-certified bond-rating agencies. J. Account. Econ. 42, 303-334.

Bebchuk, L., Cohen, A., Ferrell, A., 2009. What matters in corporate governance? Rev. Financ. Stud. 22, $783-827$.

Ben Saada, M., 2018. The impact of control quality on the non-performing loans of Tunisian listed banks. Manag. Audit. J. 33, 2-15.

Benson, B.W., Iyer, S.R., Kemper, K.J., Zhao, J., 2018. Director networks and credit ratings. Financ. Rev. 53, 301-336.

Berger, A.N., Imbierowicz, B., Rauch, C., 2016. The roles of corporate governance in bank failures during the recent financial crisis. J. Money Credit Bank. 48, 729-770.

Berle, A., Means, G., 1932. The Modern Corporation and Private Property. Macmillan, New York.

Bhojraj, S., Sengupta, P., 2003. Effect of corporate governance on bond ratings and yields: The role of institutional investors and outside directors. J. Bus. 76, 455-475. Black, F., Scholes, M., 1973. The pricing of options and corporate liabilities. J. Polit. Econ. 81 (3), 637-654.

Blumentritt, T., Mathews, T., Marchisio, G., 2013. Game theory and family business succession: an introduction. Fam. Bus. Rev. 26, 51-67.

Boateng, A., Liu, Y., Brahma, S., 2019. Politically connected boards, ownership structure and credit risk: evidence from Chinese commercial banks. Res. Int. Bus. Financ. 47, 162-173.

Bonsall, S.B., Holzman, E.R., Miller, B.P., 2017. Managerial ability and credit risk assessment. Manage. Sci. 63, $1425-1449$.

Borisova, G., Fotak, V., Holland, K., Megginson, W.L., 2015. Government ownership and the cost of debt: evidence from government investments in publicly traded firms. J. Financ. Econ. 118, 168-191.

Brogaard, J., Li, D., Xia, Y., 2017. Stock liquidity and default risk. J. Financ. Econ. 124, 486-502.

Byun, H.Y., 2007. The cost of debt capital and corporate governance practices. Asia Pacific J. Financ. Stud. 36, $765-806$.

Cao, Z.Y., Leng, F., Feroz, E.H., Davalos, S.V., 2015. Corporate governance and default risk of firms cited in the SEC's Accounting and Auditing Enforcement releases. Rev. Quant. Financ. Account. 44, 113-138.

Chen, D., 2014. The non-monotonic effect of board independence on credit ratings. J. Financ. Serv. Res. 45, 145-171.

Chen, C.H., Al-Najjar, B., 2012. The determinants of board size and independence: evidence from China. Int. Bus. Rev. 21, 831-846.

Chen, H.J., Lin, K.T., 2016. How do banks make the trade-offs among risks? The role of corporate governance. J. Bank. Financ. 72, S39-S69.

Chen, S.M., Ni, X., Tong, J.Y., 2016. Gender diversity in the boardroom and risk management: A case of R\&D investment. J. Bus. Ethics $136,599-621$.

Chen, T.K., Liao, H.H., Chen, W.H., 2017. CEO ability heterogeneity, board's recruiting ability and credit risk. Rev. Quant. Financ. Account. 49, $1005-1039$.

Cheng, M., Subramanyam, K.R., 2008. Analyst following and credit ratings. Contemp. Account. Res. 25, 1007-1043.

Cheng, M.Y., Geng, H.Y., Zhang, J.R., 2016. Chinese commercial banks: Benefits from foreign strategic investors? Pacific Basin Financ. J. 40, 147-172.

Chiang, S.M., Chung, H.M., Huang, C.M., 2015. A note on board characteristics, ownership structure and default risk in Taiwan. Account. Financ. 55, 57-74.

Cornett, M.M., Guo, L., Khaksari, S., Tehranian, H., 2010. The impact of state ownership on performance differences in privately-owned versus state-owned banks: an international comparison. J. Financ. Intermediation 19, 74-94.

Cremers, K.J.M., Nair, V.B., Wei, C.Y., 2007. Governance mechanisms and bond prices. Rev. Financ. Stud. 20, 1359-1388.

Crespi, R., Martin-Oliver, A., 2015. Do family firms have better access to external finance during crises? Corp. Gov. Int. Rev. $23,249-265$.

Demerjian, P., Lev, B., McVay, S., 2012. Quantifying managerial ability: a new measure and validity tests. Managerial Science 58, $122-1248$.

ElBannan, M.A., 2015. Do consolidation and foreign ownership affect bank risk taking in an emerging economy? An empirical investigation. Manag. Financ. 41, 874-907.

Elhaj, M.A., Muhamed, N.A., Ramli, N.M., 2018. The effects of board attributes on Sukuk rating. Int. J. Islam. Middle East. Financ. Manag. 11, 312-330.

Eun, C.S., Wang, L., Xiao, S.C., 2015. "Culture and R2". J. Financ. Econ. 115, 283-303.

Fama, E.F., Jensen, M.C., 1983. Separation of ownership and control. J. Law Econ. 26, 301-325.

Ferreira, M.A., Matos, P., 2012. Universal banks and corporate control: evidence from the global syndicated loan market. Rev. Financ. Stud. 25, $2703-2744$.

Fields, L.P., Fraser, D.R., Subrahmanyam, A., 2012. Board quality and the cost of debt capital: the case of bank loans. J. Bank. Financ. 36, $1536-1547$.

Francoeur, C., Labelle, R., Sinclair-Desgagné, B., 2008. Gender diversity in corporate governance and top management. J. Bus. Ethics 81, 83-95.

Froneberg, D., Kiesel, F., Schiereck, D., 2016. CDS and bank ownership structures: does the credit side show who advocates more risk? J. Risk. Finance 17, 169-193. Gao, K.J., Lin, W.F., 2018. Margin trading, short selling, and bond yield spread. China J. Account. Res. 11, 51-70.

Ge, W.X., Kang, T., Lobo, G.J., Song, B.Y., 2017. Investment decisions and bank loan contracting. Asian Rev. Account. 25, $262-287$.

Gharghori, P., Chan, H., Faff, R., 2006. Investigating the performance of alternative default-risk models: option-based versus accounting-based approaches. Aust. J. Manag. 31 (2), 207-234.

Ghouma, H., 2017. How does managerial opportunism affect the cost of debt financing? Res. Int. Bus. Financ. 39, 13-29.

Gompers, P., Ishii, J., Metrick, A., 2003. Corporate governance and equity prices. Q. J. Econ. 118, 107-155.

Gonzalez, F., 2005. Bank regulation and risk-taking incentives: an international comparison of bank risk. J. Bank. Financ. 29 (5), $1153-1184$.

Grassa, R., 2016. Corporate governance and credit rating in Islamic banks: Does Shariah governance matters? J. Manag. Gov. 20, 875-906.

Haque, F., Shahid, R., 2016. Ownership, risk-taking and performance of banks in emerging economies: evidence from India. J. Financ. Econ. Policy 8, $282-297$.

Hillegeist, S.A., Keating, E.K., Cram, D.P., Lundstedt, K.G., 2004. Assessing the probability of bankruptcy. Rev. Account. Stud. 9 (1), 5-34.

Hoskisson, R., Chirico, F., Zyung, J., Gambeta, E., 2017. Managerial risk taking: a multitheoretical review and future research agenda. J. Manage. 43, 137-169.

Iannotta, G., Nocera, G., Sironi, A., 2013. The impact of government ownership on bank risk. J. Financ. Intermediation 22, $152-176$.

Infante, L., Piazza, M., 2014. Political connections and preferential lending at local level: some evidence from the Italian credit market. J. Corp. Financ. 29, $246-262$.

Jensen, M.C., 1993. The modern industrial revolution, exit, and the failure of internal control systems. J. Finance 48, 831-880.

Jiraporn, P., Chintrakarn, P., Kim, J.C., Liu, Y.X., 2013. Exploring the agency cost of debt: evidence from the iss governance standards. J. Financ. Serv. Res. 44, 205-227.

John, K., De Masi, S., Paci, A., 2016. Corporate governance in banks. Corp. Gov. Int. Rev. 24, 303-321.

Karabay, B., 2010. Foreign direct investment and host country policies: a rationale for using foreign ownership restrictions. J. Dev. Econ. 93 , $218-225$.

La Porta, R., Lopez-de-Silanes, F., Shleifer, A., 1999. Corporate ownership around the world. J. Finance 54, 471-517. 
Laeven, L., Levine, R., 2009. Bank governance, regulation and risk taking. J. Financ. Econ. 93 (2), 259-275.

Lewellyn, K.B., Muller-Kahle, M.I., 2012. CEO power and risk taking: evidence from the subprime lending industry. Corp. Gov. Int. Rev. 20 , $289-307$.

Li, H., Wang, Y., 2016. How do Corporate Governance Decisions Affect Bondholders? Q. J. Finance 6 1650011-1 - 1650011-23.

Lim, H.J., Mali, D., 2018. Does market risk predict credit risk? An analysis of firm risk sensitivity, evidence from South Korea. Asia Pacific J. Account. Econ. 25, 235-252.

Lin, C., Ma, Y., Malatesta, P., Xuan, Y.H., 2011. Ownership structure and the cost of corporate borrowing. J. Financ. Econ. 100, 1-23.

Liu, Y.X., Jiraporn, P., 2010. The effect of CEO power on bond ratings and yields. J. Empir. Finance 17, 744-762.

Liu, C.L., Yeh, Y.H., 2018. Ownership concentration and bank risk: international study on acquisitions. Eur. J. Financ. 24, 761-808.

Louizi, A., Kammoun, R., 2016. Evaluation of corporate governance systems by credit rating agencies. J. Manag. Gov. 20, 363-385.

Lu, J., Boateng, A., 2018. Board composition, monitoring and credit risk: evidence from the UK banking industry. Rev. Quant. Financ. Account. 51, 1107-1128.

Maltritz, D., Molchanov, A., 2014. Country credit risk determinants with model uncertainty. Int. Rev. Econ. Financ. 29, $224-234$.

Mansi, S.A., Maxwell, W.F., Wald, J.K., 2009. Creditor protection laws and the cost of debt. J. Law Econ. 52, $701-726$.

May, D.O., 1995. Do managerial motives influence firm risk reduction strategies? J. Finance 50, 1291-1308.

Mehran, A., Morrison, A.D., Shapiro, J.D., 2011. Corporate governance and banks: what have we learned from the financial crisis? Federal Reserve Bank of New York. Report No. 502.

Merton, R.C., 1974. "On the pricing of Corporate debt: The risk structure of interest rates". J. Finance 29, 449-470.

Mili, M., Abid, S., 2016. Do corporate bond recovery rates monitored by corporate governance mechanisms? Manag. Financ. 42, 830-848.

Mollah, S., Liljeblom, E., 2016. Governance and bank characteristics in the credit and sovereign debt crises - the impact of CEO powers. J. Financ. Stab. 27, 59-73.

Morck, R., Wolfenzon, D., Yeung, B., 2005. Corporate governance, economic entrenchment, and growth. J. Econ. Lit. 43, 655-720.

Ohlson, J.A., 1980. Financial ratios and the probabilistic prediction of bankruptcy. J. Account. Res. 18 (1), $109-131$.

Pathan, S., 2009. Strong boards, CEO power and bank risk-taking. J. Bank. Financ. 33, 1340-1350.

Pfeffer, J., Salancik, G.R., 1978. The External Control of Organizations: a Resource Dependence Perspective. Harper and Row, New York, NY.

Pirson, M., Turnbull, S., 2015. The future of corporate governance: network governance - a lesson from the financial crisis. Hum. Syst. Manag. 34, 81-89.

Poletti-Hughes, J., Briano-Turrent, G.C., 2019. Gender diversity on the board of directors and corporate risk: a behavioural agency theory perspective. Int. Rev. Financ. Anal. 62, 80-90.

Roberts, M., Whited, T., 2013. Handbook of the Economics of Finance. Chapter 7: Endogeneity in Empirical Corporate Finance. pp. $493-572$.

Safiullah, M., Shamsuddin, A., 2018. Risk in Islamic banking and corporate governance. Pacific Basin Financ. J. 47, 129-149.

Saghi-Zedek, N., 2016. Product diversification and bank performance: Does ownership structure matter? J. Bank. Financ. 71, 154-167.

Saghi-Zedek, N., Tarazi, A., 2015. Excess control rights, financial crisis and bank profitability and risk. J. Bank. Financ. 55, 361-379.

Schiehll, E., Martins, H., 2016. Cross-national governance research: a systematic review and assessment. Corp. Gov. Int. Rev. 24, 181-199.

Schulze, W.S., Lubatkin, M.H., Dino, R.N., Buchholtz, A.K., 2001. Agency relationships in family firms: theory and evidence. Organ. Sci. 12, 99-116.

Shleifer, A., Vishny, R., 1986. Large shareholders and corporate control. J. Polit. Econ. 94, 461-488.

Shleifer, A., Vishny, R., 1997. A survey of corporate governance. J. Finance 52, 737-783.

Shu, P.G., Chen, T.K., Hung, W.J., 2015. Audit duration quality and client credit risk. Asia Pacific J. Account. Econ. 22, $137-162$.

Skousen, C.J., Song, X.H., Sun, L., 2018. CEO network centrality and bond ratings. Adv. Account. 40, 42-60.

Switzer, L.N., Wang, J., 2017. Institutional investment horizon, the information environment, and firm credit risk. J. Financ. Stab. 29 , 57-71.

Switzer, L.N., Tu, Q., Wang, J., 2018a. Corporate governance and default risk in financial firms over the post-financial crisis period: international evidence. J. Int. Financ. Mark. Inst. Money 52, 196-210.

Switzer, L.N., Wang, J., Zhang, Y.J., 2018b. Effect of corporate governance on default risk in financial versus nonfinancial firms: canadian evidence. Can. J. Adm. Sci. / Rev. Can. Des Sci. L Adm. 35, 313-328.

Tacneng, R., 2015. The impact of minority foreign ownership and controlling shareholder on bank risk and performance Evidence from an emerging economy. Manag. Financ. 41, 526-546.

Tanaka, T., 2016. How do managerial incentives affect the maturity structure of corporate public debt? Pacific Basin Financ. J. 40, 130-146.

Tarchouna, A., Jarraya, B., Bouri, A., 2017. How to explain non-performing loans by many corporate governance variables simultaneously? A corporate governance index is built to US commercial banks. Res. Int. Bus. Financ. 42, 645-657.

Upadhyay, A., 2015. Board size, firm risk, and equity discount. J. Risk Insur. 82, 571-599.

Utama, C.A., Utama, S., Amin, A.M., 2016. The influence of corporate governance practices and ownership structure on credit ratings: evidence from Indonesia. Asian Journal of Business and Accounting 9, 41-72.

Vandergrift, D., Brown, P., 2005. Gender differences in the use of high-variance strategies in tournament competition. J. Socio. 34, 834-849.

Villalonga, B., Amit, R., 2006. How do family ownership, control, and management affect firm value? J. Financ. Econ. 80, 385-418.

Wang, A.W., Zhang, G.Y., 2009. Institutional ownership and credit spreads: an information asymmetry perspective. J. Empir. Finance 16, 597-612.

Wintoki, M., Linck, J., Netter, J., 2012. Endogeneity and the dynamics of internal corporate governance. J. Financ. Econ. 105, 581-606.

Wooldridge, J.M., 2010. Econometric Analysis of Cross Section and Panel Data, 2nd edition. MIT Press, Cambridge, MA.

Yeh, T.M., 2017. Governance, risk-taking and default risk during the financial crisis: the evidence of Japanese regional banks. Corporate Governance-The International Journal of Business in Society 17, 212-229.

Yen, J.F., Lin, C.Y., Chen, Y.S., Huang, Y.C., 2015. Founding family firms and bank loan contracts. J. Financ. Serv. Res. 48, 53-82.

Zagorchev, A., Gao, L., 2015. Corporate governance and performance of financial institutions. J. Econ. Bus. 82, 17-41.

Zheng, C.J., Moudud-Ul-Huq, S., Rahman, M.M., Ashraf, B.N., 2017. Does the ownership structure matter for banks' capital regulation and risk-taking behavior? Empirical evidence from a developing country. Res. Int. Bus. Financ. 42, 404-421.

Zhu, W.Y., Yang, J.W., 2016. State ownership, cross-border acquisition, and risk-taking: evidence from China's banking industry. J. Bank. Financ. 71, 133-153. 